\title{
URGENSI PENCATATAN NIKAH SEBAGAI RUKUN NIKAH (STUDI KRITIS PEMIKIRAN SITI MUSDAH MULIA DAN KHOIRUDDIN NASUTION)
}

\author{
Muhammad Amin Sayyad \\ IAIN Palangka Raya, Indonesia
}

\section{ABSTRACT}

The focus of this research are about Siti Musdah Mulia's and Khoiruddin Nasution's thought and istinbāt method about urgency of marriage registration as a pillars of marriage. This research is library research. Technic of collection data using documentation dan interviews methods. This research using jurisprudence approach, Islamic law of philosophy approach (ușulal-fiqh), and comparative approach. Data presentation using descriptive and deductive method. Analysing data using the deskriptif-analitic and content analysis method. The results of these research, are: (1) Siti Musdah Mulia's thought about urgency marriage registration as a pillars of marriage was because there are many negative impacts caused by unregistered marriage or informally marriage. Istinbāt method used by Siti Musdah Mulia for determining marriage registration as a pillars of marriage is surah al-Baqarah verse 282 with the qiyas aulawi method, dilalah al-maqāșid some hadis about marriage announcement and mașlahah mursalah method, (2) Khoiruddin Nasution's thought about urgency marriage registration as a pillars of marriage was because of the changes of recognition and guarantee rights context at Prophet SAW era was enough with walimah, the announcement and witnesses, while now the recognition and guarantee right are marriage registration. Khoiruddin Nasution used combination method of thematic-holistic for determining the marriage registration as a pillars of marriage. (3) Considering conditions of the society, law, norms and social-cultural which develops upon the people of Indonesia currently then Siti Musdah Mulia and Khoiruddin Nasution's tought about marriage registration as a pillars marriage that is reviewed in a philosophic manner, juridical and sociological, it can be said was not relevant anymore. Because, the validity of marriage registration both philosophically, juridically and sociologically only as authentic proof and order marriage orde marriage orderly, so it is not the determinant of legitimacy in marriage.

Keywords: Siti Musdah Mulia, Khoiruddin Nasution, Marriage Registration,Pillars of Marriage.

ABSTRAK

Fokus dari penelitian ini adalah tentang pemikiran Siti Musdah Mulia dan Khoiruddin Nasution serta metode istinbā tentang urgensi pendaftaran pernikahan sebagai pilar pernikahan. Penelitian ini merupakan penelitian kepustakaan. Teknik pengumpulan data menggunakan metode dokumentasi dan wawancara. Penelitian ini menggunakan pendekatan yurisprudensi, pendekatan filsafat hukum Islam (ușūlal-fiqh), dan pendekatan komparatif. Presentasi data menggunakan metode deskriptif dan deduktif. Menganalisis data menggunakan metode analisis deskriptifanalitik dan konten. Hasil dari penelitian ini, adalah: (1) Pemikiran Siti Musdah Mulia tentang pentingnya pendaftaran pernikahan sebagai pilar pernikahan adalah karena ada banyak dampak negatif yang disebabkan oleh perkawinan yang tidak terdaftar atau pernikahan informal. Metode Istinbāt yang digunakan oleh Siti Musdah Mulia untuk menentukan pendaftaran nikah sebagai pilar pernikahan adalah surah al-Baqarah ayat 282 dengan metode qiyas aulawi, dilalah al- 
maqāssid beberapa hadis tentang pengumuman perkawinan dan metode ma mlaḥah mursalah, (2) pemikiran Khoiruddin Nasution tentang urgensi pencatatan perkawinan sebagai pilar pernikahan adalah karena perubahan pengakuan dan jaminan konteks hak pada zaman Nabi SAW sudah cukup dengan walimah, pengumuman dan saksi, sementara sekarang pengakuan dan jaminan yang benar adalah pendaftaran nikah. Khoiruddin Nasution menggunakan metode kombinasi tematik-holistik untuk menentukan pendaftaran pernikahan sebagai pilar pernikahan. (3) Mempertimbangkan kondisi masyarakat, hukum, norma dan sosial budaya yang berkembang pada masyarakat Indonesia saat ini maka Siti Musdah Mulia dan Khoiruddin Nasution tentang pendaftaran pernikahan sebagai pilar perkawinan yang ditinjau secara filosofis, yuridis dan sosiologis , bisa dikatakan sudah tidak relevan lagi. Karena, keabsahan pendaftaran pernikahan baik secara filosofis, yuridis dan sosiologis hanya sebagai bukti otentik dan ketertiban pernikahan orde nikah yang tertib, sehingga bukan penentu legitimasi dalam perkawinan.

Kata Kunci: Siti Musdah Mulia, Khoiruddin Nasution, Pendaftaran Pernikahan, Pilar pernikahan.

\section{A. Pendahuluan}

Indonesia bukan merupakan negara agama karena negara agama hanya mendasarkan diri pada satu agama saja, tetapi juga bukan merupakan negara sekuler karena negara sekuler sama sekali tidak mau terlibat dalam urusan agama. Indonesia adalah negara kebangsaan yang beragama didasarkan pada Pancasila (religions nation state) bertujuan untuk melindungi dan memfasilitasi perkembangan semua agama yang dipeluk oleh rakyatnya tanpa harus membedakan besarnya jumlah pemeluk. ${ }^{1}$

Relasi yang terjalin antara negara Indonesia dan agama ialah relasi yang bersifat simbiosismutualistis, di mana yang satu dengan yang lain saling membutuhkan dan bersifat timbal-balik. Agama membutuhkan negara sebagai instrumen dalam melestarikan dan mengembangkan agama. ${ }^{2}$ Begitu juga sebaliknya, negara memerlukan agama untuk membantu negara dalam pembinaan moral, etik dan spritualitas. ${ }^{3}$

Sumber kekuasaan Indonesia berasal atas rida Tuhan Yang Maha Esa, sebagaimana dalam pembukaan Undang-Undang Dasar 1945 pada alenia ketiga disebutkan bahwa "Kemerdekaan bangsa Indonesia itu atas berkat rahmat Allah Yang Maha Kuasa". Kemudian pada alenia keempat disebutkan bahwa "Negara Republik Indonesia tersusun dalam bentuk kedaulatan rakyat", yang bermakna bahwa sumber kekuasaan juga terletak di tangan rakyat. Hal inilah yang membuat sistem pemerintahan di Indonesia merupakan sistem demokrasi di mana kekuasaan berasal dari rakyat, dilaksanakan oleh rakyat dan dijalankan sebaik-baiknya untuk kepentingan

\footnotetext{
${ }^{1}$ Tengku Irwansyahbana, "Sistem Hukum Perkawinan Pada Negara Hukum Berdasarkan Pancasila", Jurnal Ilmu Hukum, Vol. 3, No. 1, 2012, h. 22.

${ }^{2}$ Dalam rangka memenuhi kewajiban negara (pemerintah) untuk melaksanakan isi Undang-Undang Dasar 1945 Pasal 29. Pasal tersebut berbunyi, ayat (1) "Negara berdasar atas ke-Tuhanan Yang Maha Esa", ayat (2) "Negara menjamin kemerdekaan tiap-tiap penduduk untuk memeluk agamanya masing-masing dan untuk beribadat menurut agamanya dan kepercayaannya itu". Maka dibentuklah Departemen Agama pada tanggal 3 Januari 1946 (lima bulan setelah proklamasi kemerdekaan). Departemen ini dibentuk untuk melindungi kebebasan beragama, menjaga keserasian hubungan antara komunitas agama yang berbeda dan yang utama adalah untuk menangani masalah muslim, seperti pendidikan Islam, perkawinan, haji, dakwah dan mengelola peradilan agama. Lihat pada Hamlan, "Politik Pendidikan Islam dalam Konfigurasi Sistem Pendidikan di Indonesia", Hunafa: Jurnal Studia Islamika, Vol. 10, No. 1, Juni, 2013, h. 182.

${ }^{3}$ Edi Gunawan,"Relasi Agama dan Negara (Perspektif Pemikiran Islam)”, Jurnal Al-Hikmah, Vol. XV, No. 2, 2014, h. 70 .
} 
rakyat. Maka untuk menegakkan negara demokrasi menurut Montesquieu, perlu diadakan pemisahan kekuasaan negara ke dalam tiga organ, yakni: kekuasaan legislatif (membuat undangundang), kekuasaan eksekutif (melaksanakan undang-undang) dan kekuasaan yudikatif (mengadili bila terjadi pelanggaran atas undang-undang). ${ }^{4}$

Menurut peneliti berdasarkan paparan di atas, Indonesia sebagai negara bangsa (nation state), dalam hal pemisahan urusan negara dan urusan agama tidak otomatis menjadikan negara Indonesia sebagai negara sekuler. Sebaliknya keterlibatan negara dalam mengurus agama tidak otomatis pula menjadikan negara Indonesia sebagai negara agama. Negara Indonesia menempatkan substansi dan nilai-nilai agama di dalam kehidupan berbangsa dan bernegara amat penting, ${ }^{5}$ sebagai buktinya salah satu produk hukum yang disahkan sebagai Undang-Undang yang dijiwai oleh agama adalah Undang-Undang No. 1 Tahun 1974 tentang Perkawinan (selanjutnya disebut UUP).

Berkaitan dengan perkawinan yang merupakan salah satu perbuatan hukum, ${ }^{6}$ di mana terdapat rukun dan syarat-syarat yang harus dipenuhi. Rukun dan syarat menentukan suatu pekerjaan/perbuatan, terutama menyangkut dengan sah atau tidaknya pekerjaan/perbuatan tersebut. Dalam konteks perkawinan Islam rukun dan syarat tidak boleh tertinggal, hal tersebut membuat perkawinan akan menjadi tidak sah bila keduanya tidak lengkap. ${ }^{7}$

Peraturan perkawinan di Indonesia UUP menentukan dua syarat perkawinan, yakni: syarat materil dan syarat formil/administratif. ${ }^{8}$ Syarat materil adalah syarat yang melekat pada setiap rukun nikah, baik yang diatur dalam fikih maupun dalam perundang-undangan. Sedangkan syarat formil/administratif adalah syarat yang berhubungan dengan pencatatan perkawinan. Dalam UUP, perkawinan dinyatakan sah apabila dilakukan menurut hukum masing-masing agamanya dan kepercayaannya itu, serta tiap-tiap perkawinan dicatat menurut peraturan

\footnotetext{
${ }^{4}$ Indonesia merupakan negara yang menganut paham trias politica yaitu suatu paham yang menyatakan bahwa cabang pemerintahan dibagi atas tiga kekuasaan, yaitu: 1) Kekuasaan legislatif oleh DPR (Pasal 20 ayat (1) UUD 1945, memegang kekuasaan membentuk Undang-Undang), 2) Kekuasaan eksekutif oleh Presiden (Pasal 4 ayat (1)UUD 1945, memegang kekuasaan pemerintahan), dan 3) Kekuasaan yudikatif oleh MK dan MA (Pasal 24 ayat (1)UUD 1945, memegang kekuasaan kehakiman yang merdeka untuk menyelenggarakan peradilan guna menegakkan hukum dan keadilan. Lihat Jimly Asshiddiqie, Pengantar Ilmu Hukum Tata Negara, Jakarta: Rajawali Pers, cet. ke-3, 2011, h. 283. Lihat juga Bernard L. Tanya, dkk, Teori Hukum: Strategi Tertib Manusia Lintas Ruang dan Waktu, Yogyakarta: Genta Publishing, cet. ke-3, 2010, h. 85-86.

${ }^{5}$ Mohammad Daud Ali secara tegas menyatakan bahwa,"Karena eratnya hubungan antara agama (dalam arti sempit) dengan hukum dalam Islam, sehingga dalam pembangunan hukum di Indonesia yang mayoritas penduduknya beragama Islam, unsur hukum dalam prinsip-prinsip hukum Islam menjadi salah satu sumber hukum dari perspektif norma agama berdasarkan Pancasila dan Undang-Undang Dasar 1945." Lihat pada Mohammad Daud Ali, Hukum Islam: Pengantar Ilmu Hukum dan Tata Hukum Islam di Indonesia, Jakarta: PT RajaGrafindo Persada, 2002, h. 245.

${ }^{6}$ Perbuatan hukum adalah perbuatan subjek hukum yang diberi akibat hukum oleh kaidah hukum tertentu dan timbulnya akibat hukum ini dikehendaki oleh subjek hukum. Sebagaimana perkawinan merupakan perbuatan subjek hukum antara kedua belah pihak baik mempelai laki-laki dan perempuan yang secara sengaja melakukan perikatan untuk membentuk kehidupan rumah tangga atau berkeluarga dan dari ikatan tersebut timbulnya hak dan kewajiban antara suami-istri. Lihat pada Donald Albert Rumokoy dan Frans Maramis, Pengantar Ilmu Hukum, Jakarta: PT RajaGrafindo Persada, cet. ke-2, 2014, h. 128. Lihat juga Muhammad Erwin dan Firman Freaddy Busroh, Pengantar Ilmu Hukum, Bandung: Refika Aditama, cet. ke-1, 2012, h. 53. Lihat juga M. Efran Helmi Juni, Filsafat Hukum, Bandung: Pustaka Setia, cet. ke-1, 2012, h. 66.

${ }^{7}$ Amir Syarifuddin, Hukum Perkawinan Islam di Indonesia antara Fiqh Munakahat dan Undang-Undang Perkawinan, Jakarta: Kencana, 2006, h. 59.

${ }^{8}$ R. Otje Salman Soemadiningrat, Rekonseptualisasi Hukum Adat Kontemporer: Telaah Kritis terhadap Hukum Adat sebagai Hukum yang Hidup dalam Masyarakat, Bandung: Alumni, cet. ke-1, 2002, h.175.
} 
perundang-undangan yang berlaku. ${ }^{9}$ Sementara itu dalam PP No. 9 Tahun 1975 tentang Peraturan Pelaksanaan UUP Pasal 2 ayat (1) disebutkan:

"Pencatatan perkawinan dari mereka yang melangsungkan perkawinannya menurut agama Islam, dilakukan oleh Pegawai Pencatat, sebagaimana dimaksud dalam Undang-Undang Nomor 32 Tahun 1954 tentang Pencatatan Nikah, Talak dan Rujuk." 10

Permasalahan pencatatan perkawinan tidak ditemukan dalam kitab-kitab fikih klasik. Menurut jumhur ulama suatu perkawinan dianggap sah apabila telah memenuhi rukun dan syarat perkawinan. Terdapat beberapa respon dalam menanggapi pencatatan perkawinan ini sebagai syarat dalam perkawinan, sehingga menimbulkan kontroversi di dalam masyarakat Indonesia. Kelompok yang pro secara umum adalah kelompok sarjana dan ahli hukum yang selama ini tunduk dan melaksanakan perkawinan berdasarkan UUP. Mereka berpendapat mulai sahnya perkawinan adalah setelah pendaftaran atau pencatatan perkawinan yang menjadikan sebuah akta nikah. Menurut mereka perkawinan yang tidak dicatatkan memiliki banyak dampak negatif (mudarat), di antaranya: 1) istri tidak dianggap sebagai istri sah, 2) istri tidak dapat menuntut hak nafkah dan warisan jika suami meninggal dunia, 3) istri tidak berhak atas harta gono-gini jika terjadi perpisahan atau perceraian, 4) istri sulit bersosialisasi karena nikah siri dianggap kumpul kebo atau dianggap sebagai istri simpanan, 5) istri mengalami kekerasan dalam rumah tangga, ${ }^{11}$ 6) anak hanya memiliki hubungan keperdataan kepada ibu, 7) anak tidak bisa masuk sekolah, 8) anak lebih cenderung mengalami kekerasan ${ }^{12}$, 9) suami berpeluang menikah lagi dengan istri kedua, ketiga dan keempat (poligami) serta masih banyak lagi dampak negatif dari perkawinan yang tidak dicatatkan. ${ }^{13}$

Adapun kelompok kontra adalah kaum muslim yang tradisionalis dan juga banyak ahli hukum. Menurut mereka saat mulai sahnya perkawinan bukan pada saat pendaftaran atau pencatatan, hal tersebut hanyalah bersifat administratif. Sedang saat mulai sahnya perkawinan adalah setelah terjadinya ijab dan kabul. ${ }^{14}$ Selain itu, terdapat beberapa dampak positif (manfaat) bagi nikah siri atau tidak dicatatkan, di antaranya: 1) meminimalisir perzinaan atau prostitusi, yang mengakibatkan berkembangnya penyakit HIV, AIDS maupun penyakit kelamin yang lain, 2) lebih hemat biaya, 3) lebih praktis dan cepat daripada melalui prosedur dari pemerintah yang berbelit-belit, 4) nikah siri tidak perlu ijin istri pertama, 5) mengurangi beban atau tanggung

${ }^{9}$ Tim Permata Press, Undang-Undang Perkawinan \& Administrasi Kependudukan, Kewarganegaraan, t.tp: Permata Press, t.th, h. 2.

${ }^{10}$ Peraturan Pemerintah No. 9 tahun 1975 tentang Pelaksanaan Undang-Undang No. 1 tahun 1974 tentang Perkawinan, Pasal 2 ayat (1).

${ }^{11}$ Siaran pers Lembaga Bantuan Hukum (LBH) APIK pada akhir Maret 2009 mencatat perempuan yang mengalami kasus KDRT sebanyak 77,8\% dari 160 kasus, yaitu 130 kasus. Dari 130 kasus tersebut, sebanyak 43,4\% menggugat cerai akibat dari nikah siri. Sisanya 56,6\% merupakan istri sah yang menggugat cerai karena suaminya menikah siri lagi dan menelantarkan rumah tangganya. Lihat pada Muhammad Budiono, "Dampak Sosial Nikah Siri", Al-Hukama, Vol. 3, No. 1, Juni, 2013, h. 592.

${ }^{12}$ Berdasarkan data yang diperoleh Komisi Perlindungan Anak Indonesia (KPAI) dari tahun 2011-2014, ada 46 laporan anak yang mendapatkan kekerasan akibat pernikahan siri atau sebanyak 8\%. Angka tersebut hanya untuk wilayah Jakarta, Bogor, Depok, Tanggerang dan Bekasi (Jabodetabek). Lihat KPAI: Nikah Siri Bisa Berdampak Buruk ke Anak, Http://news.merahputih.com/nasional/2015/ 03/24/kpai-nikah-siri-bisa-berdampak-buruk-ke-anak/9465/. (Online pada hari Kamis, 19 Mei 2016).

${ }^{13}$ Thriwaty Arsal, "Nikah Siri dalam Tinjauan Demografi”, Solidaty: Jurnal Sosiologi Pedesaan, Vol. 6, No. 2, 2012, h. 166. Lihat juga Tim Penulis, Isu-Isu Gender Kontemporer dalam Hukum Keluarga, Malang: UINMaliki Press, cet. ke-1, 2010, h. 77.

${ }^{14}$ Afifah Zakiyah Sufa, Tinjauan Hukum Islam terhadap Fungsi Akta Nikah (Studi terhadap Pemahaman Masyarakat Desa Maguwoharjo Kecamatan Depok Kabupaten), Yogyakarta: UIN Sunan Kalijaga, 2015 , t.d, h. 4. 
jawab seorang wanita yang menjadi tulang punggung keluarganya, 6) menghindari fitnah dari orang sekitar. ${ }^{15}$

Implikasi dari pandangan tersebut menurut peneliti baik yang pro maupun yang kontra tentang pencatatan perkawinan mengakibatkan dualisme hukum yang mana apabila terpenuhinya rukun dan syarat perkawinan secara agama maka nikah tersebut sah, tetapi di sisi lain terpenuhinya rukun dan syarat perkawinan secara agama saja tidak cukup melainkan harus dicatatkan. Dampak dari dualisme hukum perspektif masyarakat tersebut adalah tidak terlaksananya pencatatan perkawinan yang diatur dalam perundang-undangan di Indonesia dengan baik. Di antara warga negara Indonesia banyak yang tidak mencatatkan perkawinannya kepada Pegawai Pencatat Nikah (PPN). ${ }^{16}$ Perkawinan yang dilakukan oleh mereka hanya memenuhi tuntutan agamanya tanpa memenuhi tuntutan administratif. Salah satu sebabnya adalah karena ketidaktegasan hukum pencatatan perkawinan. ${ }^{17}$

Melihat dampak negatif ketidaktegasan hukum pencatatan perkawinan di Indonesia, ${ }^{18}$ ada sebuah gagasan revolusioner dalam memberikan respon, tanggapan dan pemikirannya mengenai pencatatan perkawinan. Sebagian di antaranya adalah Siti Musdah Mulia dan Khoiruddin Nasution. Pemikiran kedua tokoh muslim di atas menarik untuk dikaji dan sekiranya membuka peluang bagi para intelektual lainnya serta masyarakat umum untuk ikut memberikan respon serta tanggapan perihal pencatatan nikah. Sebab, tidak dapat dipungkiri bahwa pemikiran mereka juga dapat memberikan pengaruh terhadap cara pandang masyarakat mengenai persoalan hukum tertentu.

Siti Musdah Mulia salah seorang aktivis gender berpendapat pencatatan perkawinan dapat dijadikan sebagai rukun atau syarat sah perkawinan karena untuk kemaslahatan istri dan anak dalam perkawinan. Lebih jelasnya pernyataan beliau, sebagai berikut:

"Meski secara agama atau adat istiadat, perkawinan yang tidak tercatat adalah sah, di mata hukum ia tidak memiliki kekuatan hukum. Perkawinan yang tidak tercatatkan berdampak sangat merugikan bagi istri dan perempuan pada umumnya. Bagi istri, dampaknya secara hukum adalah dia tidak akan dianggap sebagai istri yang sah karena tidak memiliki 'akta nikah' atau 'buku nikah' sebagai bukti hukum yang autentik. Akibat lanjutannya, istri tidak berhak atas harta gonogini jika terjadi perceraian karena secara hukum perkawinan tersebut dianggap tidak pernah terjadi. Dampaknya terhadap anak juga tidak kalah beratnya. Status anak yang dilahirkan pun akan dianggap sebagai anak tidak sah. Akta kelahirannya hanya berupa akta pengakuan, misalnya dicantumkan 'anak luar nikah' atau 'anak yang lahir dari ibu dan diakui oleh seorang bapak'. Untuk perbaikan ke depan kita mengusulkan agar kedua ayat dalam pasal 2 ayat (1) dan (2) UUP hendaknya digabungkan menjadi satu sehingga berbunyi seperti berikut: Perkawinan

${ }^{15}$ Siti Ummu Abdillah, "Analisis Hukum terhadap Faktor-faktor yang Melatarbelakangi Terjadinya Nikah Siri dan Dampaknya terhadap Perempuan (Istri) dan Anak-anak", Jurnal Dinamika Hukum, Vol. 11, Februari, 2011, h. 108.

${ }^{16}$ Berdasarkan hasil penelitian Ahmad Tholabi Kharlie pada tahun 2002 yang dilakukan di Kantor Urusan Agama (KUA) di Kabupaten Lebak, Banten, terungkap bahwa kesadaran masyarakat untuk mencatatkan pernikahan di KUA cukup rendah, yakni $46,7 \%$ dari responden yang mencatatkan pernikahannya, sedangkan para pihak yang melakukan pernikahan di bawah tangan sebanyak 53,3\%. Lihat Ahmad Tholabi Kharlie, Hukum Keluarga Indonesia, Jakarta: Sinar Grafika, cet. ke-1, 2013, h. 192-193.

${ }^{17}$ Masruhan,"Pembaharuan Hukum Pencatatan Perkawinan di Indonesia Perspektif Maqasid Syariah", $\mathrm{Al}$ Tahrir, Vol. 13, No. 2, November, 2013, h. 235.

${ }^{18}$ Ketidaktegasan aturan pencatatan perkawinan dapat dilihat pada Undang-Undang Nomor 1 Tahun 1974 tentang Perkawinan pada Pasal 2 ayat (1) dan (2). 
adalah sah apabila dilakukan menurut hukum masing-masing agama dan kepercayaannya itu dan wajib dicatat menurut peraturan perundang-undangan yang berlaku. Selanjutnya disertakan sanksi yang ketat bagi yang melanggar dan sanksi itu betul-betul dilaksanakan sehingga efektif menghalangi munculnya kasus-kasus perkawinan bawah tangan (yang jelas-jelas merugikan perempuan)."19

Berbeda dengan pendapat Musdah, Khoiruddin Nasution menjadikan pencatatan nikah sebagai syarat dan/atau rukun perkawinan karena adanya kesamaan 'illah (sebab/motif hukum) dari walimah, pengumuman dan saksi pernikahan dengan pencatatan nikah. Dalam hal ini beliau menyatakan:

"Ada perubahan bentuk dengan 'illah yang sama di masa Nabi dan masa sekarang. Sesuai dengan perubahan dan perkembangan zaman. 'Illah dari walimahan, pengumuman dan saksi yang berlaku di masa Nabi Muhammad SAW adalah pengakuan masyarakat dan penjaminan hak. Sementara bentuk pengakuan dan jaminan hak untuk masa sekarang tidak cukup lagi kalau hanya dengan walimahan dan pengumuman, tetapi diperlukan bukti tertulis (akta). Maka di sinilah letak relevansi pentingnya pencatatan perkawinan. ${ }^{20}$ Kalau ada perkawinan yang tidak dicatatkan dengan maksud/tujuan untuk merahasiakan, maka perkawinan tidak sah, sebab perkawinan yang dirahasiakan atau dilakukan dengan terpaksa pasti sulit untuk mencapai tujuan perkawinan.",21

Berdasarkan latar belakang di atas peneliti tertarik ${ }^{22}$ untuk melakukan penelitian dengan rumusan masalah bagaimana pemikiranSiti Musdah Mulia dan Khoiruddin Nasution tentang pencatatan perkawinandan bagaimana relvansinya dengan hukum dan peraturan di Indonesia.

\section{B. Pembahasan}

\section{Pemikiran Siti Musdah Mulia tentang Pencatatan Nikah}

Secara implisit keabsahan perkawinan dalam pandangan Siti Musdah Mulia adalah berangkat dari definisi beliau terhadap perkawinan itu sendiri. Adapun pernyataan beliau adalah sebagai berikut, "perkawinan adalah sebuah akad atau kontrak yang mengikat dua pihak yang setara, yaitu laki-laki dan perempuan yang masing-masing telah memenuhi persyaratan

${ }^{19}$ Siti Musdah Mulia, Muslimah Reformis: Perempuan Pembaru Keagamaan, Bandung: Mizan, cet. ke-1, 2005, h. 363-364. Lihat juga Siti Musdah Mulia, Membangun Surga di Bumi: Kiat-Kiat Membina Keluarga Ideal dalam Islam, Jakarta: PT Elex Media Komputindo, 2011, h. 185.

${ }^{20}$ Khoiruddin Nasution, Hukum Perdata (Keluarga) Islam Indonesia dan Perbandingan Hukum Perkawinan di Dunia Muslim,Yogyakarta: ACAdeMIA + TAZZAFA, cet. ke-1, 2009, h. 368.

${ }^{21}$ Khoiruddin Nasution, "Pencatatan Sebagai Syarat atau Rukun Perkawinan: Kajian Perpaduan Tematik dan Holistik", Musawa, Vol. 12, No. 2, Juli, 2013, h. 182-184.

${ }^{22}$ Selain dari uraian latar belakang di atas yang membuat peneliti tertarik untuk meneliti permasalahan pencatatan nikah sebagai rukun nikah, ada beberapa faktor yang membuat peneliti tertarik untuk meneliti kedua tokoh tersebut, di antaranya adalah: 1. Dari segi keilmuan, keduanya merupakan guru besar yang berkewarganegaraan Indonesia. Siti Musdah Mulia adalah ahli di bidang pemikiran politik Islam. Sedangkan Khoiruddin Nasution ahli di bidang hukum keluarga Islam, 2. Dari segi karya dan gagasan, keduanya memiliki banyak karya baik berupa buku-buku yang diterbitkan maupun dalam bentuk jurnal. Siti Musdah Mulia memiliki banyak karya yang dalam kajiannya banyak membahas tentang gender dan HAM. Dan tidak sedikit pula dari karya beliau yang membahas tentang perkawinan, bahkan pernah mengajukan CLD-KHI atas revisi KHI-Inpres. Sedangkan Khoiruddin Nasution memiliki banyak karya yang lebih dominan membahas tentang hukum keluarga. Beliau juga menawarkan metode tematik-holistik dalam menganalisis permasalahan hukum keluarga di Indonesia, 3. Dari segi pemikiran, keduanya sama-sama mengusulkan dan menegaskan pencatatan nikah sebagai rukun nikah. 
berdasarkan hukum yang berlaku atas dasar kerelaan dan kesukaan kedua belah pihak untuk membentuk keluarga." 23

Perkawinan dari definisi di atas, dalam pandangan Siti Musdah Mulia lebih menitikberatkan pada aspek akad (kontrak), yakni suatu perjanjian hukum (legal agreement) antara seorang laki-laki dan perempuan yang masing-masing telah memenuhi persyaratan yuridis formal. Adapun perkawinan yang selama ini dipahami dan dijabarkan dalam Undang-Undang Perkawinan terkesan sangat ideal menurut Siti Musdah Mulia, karena dalam istilah yuridis (hukum) tidak dikenal dengan "ikatan lahir batin" serta "kebahagiaan yang kekal" dua hal tersebut lebih bersifat abstrak. Sedangkan hukum hanya melihat persoalan yang tampak (konkret). ${ }^{24}$

Menurut peneliti, definisi perkawinan yang dikemukakan oleh Siti Musdah Mulia sama dengan konsep perkawinan dalam hukum perdata. Perkawinan dalam aturan hukum perdata hanya menekankan pada aspek ikatan perdata. Pada Pasal 26 Kitab Undang-Undang Hukum Perdata (selanjutnya disebut KUHPer) disebutkan bahwa "Undang-Undang hanya memandang soal perkawinan hanya dalam hubungan-hubungan perdata." Adapun agama dalam perkawinan menurut hukum perdata adalah tidak begitu penting. Pasal 50 KUHPer menegaskan "Semua orang yang hendak melangsungkan perkawinan, harus memberitahukan hal itu kepada Pegawai Catatan Sipil di tempat salah satu pihak." Pasal 81 KUHPer juga menegaskan, bahwa "Tidak ada upacara keagamaan yang boleh diselenggarakan, sebelum kedua belah pihak membuktikan kepada pejabat agama mereka bahwa perkawinan di hadapan Pegawai Catatan Sipil telah berlangsung." 25 Dengan demikian, keabsahan perkawinan dalam hukum perdata adalah harus dicatatkan, jika tidak dilakukan terlebih dahulu di hadapan Pegawai Catatan Sipil maka perkawinan tersebut tidak sah.

Siti Musdah Mulia memandang bahwa aturan pencatatan perkawinan di Indonesia tidak berjalan dengan efektif. Hal ini disebabkan pemahaman masyarakat tentang sahnya perkawinan adalah apabila sudah dilakukan berdasarkan hukum agama meskipun tidak tercatat. Titik tolak pemahaman masyarakat tersebut berangkat dari pandangan Imam Syafi'i tentang syarat sahnya perkawinan apabila telah memenuhi lima unsur, yaitu adanya kedua mempelai, ijab kabul, saksi, dan wali. ${ }^{26}$ Siti Musdah Mulia mengusulkan agar aturan tersebut bisa berjalan dengan baik maka redaksi Pasal 2 ayat (1) dan (2) UUP itu digabung menjadi satu, sehingga pasal tersebut berbunyi, perkawinan adalah sah apabila dilakukan menurut hukum masing-masing agama dan kepercayaannya itu dan wajib dicatat menurut peraturan perundang-undangan yang berlaku. ${ }^{27}$

Siti Musdah Mulia juga mengusulkan agar disertai sanksi ketat bagi yang melanggar dan sanksi tersebut betul-betul dilaksanakan agar efektif untuk menekan angka perkawinan di bawah tangan yang sangat merugikan pihak perempuan. Alternatif lain yang juga ditawarkan Siti Musdah Mulia adalah memasukkan pencatatan nikah sebagai salah satu rukun nikah dan negara berkewajiban mencatatkan semua perkawinan yang terjadi. Hal ini disebabkan masing-masing mazhab fikih berbeda-beda dalam rumusan rukun nikah, sehingga rukun nikah yang diformulasikan oleh masing-masing mazhab sifatnya tidak mutlak, yang pada akhirnya

\footnotetext{
${ }^{23}$ Siti Musdah Mulia, Muslimah Reformis: Perempuan, h. 363.

${ }^{24}$ Ibid.

${ }^{25}$ Seri Hukum dan Perundangan: KitabUndang-Undang Hukum Perdata, Tanggerang: SL Media, t.th, h.

${ }^{26}$ Siti Musdah Mulia, Muslimah Reformis: Perempuan, h. 363.

${ }^{27}$ Ibid.
} $15-28$. 
berpeluang untuk memasukkan pencatatan sebagai rukun nikah. ${ }^{28}$ Selain itu, Siti Musdah Mulia menganalogikannya dengan surah al-Baqarah ayat 282 yang menyatakan bahwa dalam melaksanakan transaksi penting seperti utang-piutang hendaknya selalu dicatatkan. Artinya, perkawinan yang merupakan transaksi yang lebih krusial dari transaksi-transaksi lainnya, maka wajib pula perkawinan itu dicatatkan. ${ }^{29}$

Counter Legal Draft Kompilasi Hukum Islam (CLD-KHI) yang diajukan Tim Pengarusutamaan Gender (PUG) Departemen Agama tahun 2004 lalu secara tegas telah menyatakan dalam Pasal 6 bahwa, "Perkawinan dinyatakan sah apabila memenuhi rukun berikut: a) calon suami, b) calon istri, c) ijab dan kabul, d) saksi, e) pencatatan." Dengan demikian, pencatatan perkawinan merupakan salah satu syarat sahnya perkawinan, tanpa pencatatan, perkawinan batal secara hukum. Pelakunya harus mendapatkan sanksi karena telah melakukan perlanggaran terhadap hukum yang berlaku. Hanya saja, CLD-KHI belum sampai merumuskan secara konkret sanksi hukum terhadap para pelanggarnya. ${ }^{30}$

Peneliti menilai bahwa definisi perkawinan yang diuraikan oleh Siti Musdah Mulia nampaknya lebih menitikberatkan pada aspek keperdataan ketimbang aspek keagamaan. Artinya, perkawinan dikembalikan pada definisi yang ada di dalam hukum perdata. Sehingga keabsahan perkawinan harus tunduk pada peraturan perundang-undangan. Namun, peneliti menilai bahwa perkawinan tidak hanya dilihat dari satu sudut pandang, akan tetapi juga harus dilihat dari sudut pandang yang lain. Sebagaimana menurut Muhammad Amin Suma, paling tidak menurut sebagian ahli hukum, di antaranya Sayuti Thalib dan Mohd. Idris Ramulyo, perkawinan harus dilihat dari tiga segi pandangan, yaitu:

1) Perkawinan dari segi sosial.

2) Perkawinan dari segi hukum.

3) Perkawinan dari segi agama.

Perkawinan dari segi sosial ialah bahwa dalam setiap masyarakat (bangsa), ditemui suatu penilaian yang umum bahwa orang yang berkeluarga atau pernah berkeluarga (dianggap) mempunyai kedudukan yang lebih dihargai (terhormat) dari mereka yang tidak menikah. Adapun perkawinan dari segi hukum dipandang sebagai suatu perbuatan (peristiwa) hukum, yakni perbuatan dan tingkah laku subjek hukum yang membawa akibat hukum, karena hukum mempunyai kekuatan mengikat bagi subjek hukum atau karena subjek hukum itu terikat oleh kekuatan hukum. Sedangkan perkawinan dari sudut pandang agama (khususnya Islam) merupakan sesuatu hal yang dipandang suci (sakral). Oleh sebab itu, perkawinan tidak hanya persoalan perbuatan hukum dan memiliki penghargaan sosial di mata masyarakat, akan tetapi lebih dari itu, perkawinan juga memiliki nilai-nilai ibadah. Dengan demikian agama Islam telah menetapkan tata aturan pernikahan berikut hal-hal yang terkait dengannya sedemikian rupa dan meletakkan dasar-dasar pergaulan hidup dan hubungan suatu keluarga yang terbentuk akibat dari pernikahan itu sendiri. ${ }^{31}$

Peneliti menilai pemikiran Siti Musdah Mulia tentang pencatatan nikah sebagai rukun perkawinan, dengan konsekuensi dari perkawinan yang tidak dicatat adalah tidak sah secara hukum dan dapat dibatalkan oleh negara, namun bukan tidak sah secara agama. ${ }^{32}$ Sebab dari

\footnotetext{
${ }^{28}$ Wawancara dengan Siti Musdah Mulia tanggal 15 Januari 2017.

${ }^{29}$ Ibid., h. 363-364.

${ }^{30}$ Siti Musdah Mulia, Membangun Surga di Bumi, h. 180.

${ }^{31}$ Muhammad Amin Suma, Hukum Keluarga Islam, h. 79-81.

${ }^{32}$ Wawancara dengan Siti Musdah Mulia tanggal 15 Januari 2017.
} 
pernyataan beliau "tidak sah secara hukum dan dapat dibatalkan oleh negara" mengandung arti tidak sah secara yuridis, yang menunjukkan ada perbedaan subtansial dengan rukun nikah yang telah disepakati oleh jumhur ulama. Tujuan diadakannya rukun nikah menurut peneliti adalah agar pernikahan dilaksanakan sesuai dengan ketentuan yang telah ditetapkan oleh jumhur ulama, sehingga pernikahan tersebut sah menurut hukum Islam (fikih) yang pada akhirnya sah menurut agama, karena mendapat legitimasi baik secara langsung maupun tidak langsung dari nas. Hal ini sejalan dengan pandangan Abdul Gani Abdullah yang dikutip oleh Anshary MK, yang membagi akad nikah dalam dua asas legalitas yang berbeda. Pertama, apabila akad nikah yang telah memenuhi ketentuan agama, maka akad nikah itu sah menurut ajaran agama. Kedua, akad nikah yang telah memenuhi ketentuan agama juga harus dicatatkan, agar akad nikah itu memiliki akibat hukum yang diakui dan dilindungi secara hukum. ${ }^{33}$

Hemat peneliti, perkawinan yang telah memenuhi rukun dan syarat yang diatur norma agama (adanya mempelai laki-laki dan perempuan, ijab kabul, wali dan saksi) adalah sah secara normatif-teologis, sedangkan perkawinan yang telah memenuhi persyaratan yang diatur dalam norma hukum (melaksanakan pencatatan nikah) adalah sah secara normatif-yuridis. Artinya, perkawinan yang telah memenuhi rukun dan syarat perkawinan dalam hukum Islam, walaupun belum dicatatkan adalah sah. Namun, perkawinan tersebut tidak memiliki keabsahan yang diakui oleh negara. Sehingga perkawinan tersebut tidak mempunyai kepastian hukum yang dapat menjamin hak-hak keperdataan bagi suami-istri dan anak. Karena antara rukun nikah dan pencatatan memiliki konsekuensi hukum yang berbeda, maka pencatatan tidak dapat dijadikan sebagai rukun nikah.

Menurut peneliti, usulan Siti Musdah Mulia untuk penggabungan redaksi Pasal 2 ayat (1) dan (2) UUP adalah tidaklah begitu signifikan, karena pada dasarnya yang dikehendaki dari pencatatan nikah tersebut adalah agar sah secara hukum, bukan sah secara agama. Hal ini justru sudah diatur pada Pasal 4, 5, 6 dan 7 KHI, di mana KHI menempatkan pencatatan nikah sebagai syarat yang menentukan kekuatan hukum suatu perkawinan. Hanya perkawinan yang telah dicatat Pegawai Pencatat Nikah yang mempunyai kekuatan hukum mengikat. ${ }^{34}$

Peneliti menilai mengenai analogi Siti Musdah Mulia tentang pencatatan nikah dengan ayat mudāyanahtentang pencatatan dalam transaksi muamalah (utang-piutang) menunjukkan inkonsistensi pemikiran. Sebab, pada definisi perkawinan yang dikemukakan Siti Musdah Mulia hanya menekankan pada aspek keperdataan (kontrak sosial) daripada aspek agama. Tetapi, ketika Siti Musdah Mulia menganalogikan dengan surah al-Baqarah ayat 282 justru beliau menyatakan bahwa perkawinan merupakan transaksi yang lebih penting dari transaksi-transaksi yang lain, perkawinan dalam Islam merupakan ikatan yang kokoh/teguh/kuat sebagaimana dalam surah an-Nisā ayat 21 dengan kata mïsāqan galīzan. Walaupun demikian, peneliti sepakat bahwa perkawinan merupakan ikatan yang kokoh atau kuat dan melebihi dari ikatan-ikatan yang lain. Sehingga dari surah al-Baqarah ayat 282 tersebut Siti Musdah Mulia mewajibkan pernikahan untuk dicatatkan, dengan dicatatkannya perkawinan di hadapan Pegawai Pencatatan Nikah maka akan memberikan perlindungan hukum terhadap hak-hak keperdataan bagi pasangan suami-istri dalam pernikahan.

Siti Musdah Mulia mengakui bahwa pencatatan nikah tidak ditemukan dalam kitab-kitab fikih klasik. Hal ini disebabkan pada saat itu kehidupan manusia masih sangat sederhana, dan pencatatan belum menjadi kebutuhan pokok. Namun seiring dengan berjalannya waktu, terjadi

\footnotetext{
${ }^{33}$ Anshary MK, Hukum Perkawinan di Indonesia, h. 23.

${ }^{34}$ Departemen Agama RI, Kompilasi Hukum Islam, h. 15-16.
} 
perubahan yang demikian pesat akibat kemajuan teknologi dan dinamika masyarakat yang berimbas pada pola kehidupan keluarga sesuai tuntutan zaman. Kehidupan manusia semakin kompleks dan rumit. Pencatatan menjadi suatu kebutuhan demi kemaslahatan manusia. ${ }^{35}$ Hemat peneliti, pemikiran Siti Musdah Mulia sejalan dengan kaidah,

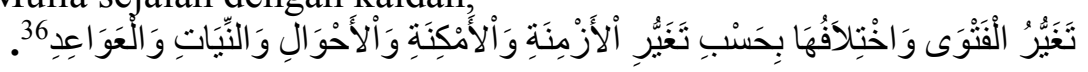

Artinya : Perubahan fatwa dan perbedaan di dalamnya mengikuti perubahan zaman, tempat, keadaan, niat dan adat kebiasaan.

Siti Musdah Mulia menjadikan pencatatan nikah sebagai rukun nikah dengan tujuan untuk kemaslahatan/melindungi pihak perempuan dan anak dalam hubungan perkawinan. Perkawinan yang tidak dicatat akan berdampak merugikan bagi istri dan anak-anak. Secara hukum, istri tidak dianggap sebagai istri yang sah karena tidak memiliki "akta nikah", istri tidak berhak mendapatkan nafkah dan warisan suami yang meninggal dan istri tidak berhak atas harta gonogini jika terjadi perceraian. Selanjutnya, anak yang dilahirkan pun akan dianggap sebagai anak tidak sah. Akta kelahirannya hanya berupa akta pengakuan, misalnya dicantumkan "anak luar nikah" atau "anak yang lahir dari ibu dan diakui oleh seorang bapak." Dengan demikian anak hanya memiliki hubungan keperdataan dengan ibu dan keluarga ibunya dan tidak mempunyai hubungan hukum dengan ayahnya (sebagaimana tercantum pada Pasal 42 dan 43 UUP). Pencatuman anak luar nikah tersebut akan mempengaruhi secara sosial dan psikologis si anak dan ibunya. Ketidakjelasan status anak di mata hukum juga berdampak pada hak-haknya untuk mendapatkan nafkah, warisan, biaya kehidupan dan pendidikan dari ayahnya. Selain berdampak hukum, perkawinan bawah tangan (tidak dicatat) juga membawa dampak sosial bagi perempuan. Akibatnya, perempuan akan sulit bersosialisasi di masyarakat karena mereka sering dianggap sebagai istri simpanan atau kumpul kebo, yakni tinggal serumah tanpa menikah. ${ }^{37}$

Peneliti sependapat, bahwa pernikahan yang tidak dicatat (di bawah tangan) adalah berdampak mudarat bagi pasangan suami-istri, khususnya yang paling banyak dirugikan adalah pihak istri. Hanya saja, peneliti bertolak belakang jika pencatatan nikah dijadikan rukun nikah dengan berdasarkan kemaslahatan semata. Sebab, unsur pernikahan seperti adanya mempelai laki-laki, mempelai perempuan, ijab-kabul, wali dan saksi yang telah disepakati ulama sebagai rukun nikah tidak hanya didasarkan pada alasan untuk kemaslahatan pernikahan. Akan tetapi, pada dasarnya adanya rukun nikah yang telah disepakati jumhur ulama merupakan unsur/hakikat yang mewujudkan suatu pernikahan. ${ }^{38}$

Menurut peneliti, urgensi ijab kabul dalam pernikahan adalah sebagai wujud konkret dari rasa kerelaan dan kesukaan antara pihak laki-laki dan perempuan yang mengikatkan diri dalam pernikahan, karena kerelaan dan kesukaan tersebut sifatnya abstrak (tidak dapat diukur), maka untuk mewujudkan/membuktikannya adalah dengan ijab dan kabul. Urgensi mempelai pengantin (laki-laki dan perempuan) adalah sebagai pelaksana ijab kabul, yang mana pada pelaksanaannya wali dari mempelai perempuan yang mengucapkan ijab (permintaan untuk menikah) dan mempelai laki-laki yang mengucapkan kabul (penerimaan untuk menikah). Urgensi wali nikah adalah sebagai wakil dari mempelai perempuan, karena pada dasarnya perempuan memiliki sifat dasar pemalu, maka walilah yang mengucapkan ijab dalam pernikahan. Urgensi saksi nikah

\footnotetext{
${ }^{35}$ Siti Musdah Mulia, Membangun Surga di Bumi, h.184.

${ }^{36}$ Muhammad ibn Abī Bakr ibn Ayyub ibn Sa'ad ibn Hariz az-Zar'i ibn Qayyimal-Jauziyyah, I'lām alMuwaqqi'in, h. 5.

${ }^{37}$ Wawancara dengan Siti Musdah Mulia tanggal 19 Desember 2016.

${ }^{38}$ Amir Syarifuddin, Hukum Perkawinan Islam, h. 59.
} 
adalah menyaksikan akad nikah dan mengucapkan sah. Selain itu, saksi juga sebagai penentu dan pemisah antara halal dan haram. Pernikahan merupakan perbuatan halal yang dilaksanakan secara terbuka, maka harus disaksikan oleh saksi. Sedangkan perzinaan merupakan perbuatan haram yang dilaksanakan secara sembunyi-sembunyi. Adapun urgensi pencatatan nikah adalah untuk melindungi hak-hak suami-istri dan anak akibat dari perkawinan yang sah.

Menurut hemat peneliti, urgensi adanya mempelai laki-laki dan perempuan, ijab kabul, wali dan saksi nikah adalah merupakan unsur pokok/inti dalam pernikahan. Apabila salah satu unsur pokok pernikahan tersebut tidak terpenuhi, maka pernikahan tidak akan terwujud atau tidak sah. Sedangkan urgensi pencatatan nikah adalah untuk melindungi akibat hukum dari pernikahan yang sah. Dengan ungkapan lain, adanya mempelai laki-laki dan perempuan, wali dan saksi dalam kajian ușülal-fiqh adalah sebagai subjek hukum (mahkkum 'alaih) dalam akad nikah. Objek hukum (mahkum fih) dalam akad nikah adalah pernikahan itu sendiri sebagai bentuk perbuatan mukallaf, dan sigah (ijab kabul). Apabila unsur pokok pernikahan tersebut telah terpenuhi, maka sahlah perkawinan dan timbullah akibat hukum, yakni hak dan kewajiban antara suami-istri. Untuk menjamin dan melindungi hak-hak dalam pernikahan, maka diperlukanlah suatu pencatatan agar memiliki bukti yang autentik. Hal ini menunjukkan bahwa pencatatan tidak berkaitan dengan unsur pokok pernikahan, tetapi berkaitan dengan akibat yang terjadi setelah pernikahan dilangsungkan. Oleh sebab itu hukum yang berkaitan dengan unsur pokok pernikahan berbeda kedudukannya dengan hukum yang berkaitan dengan akibat yang ditimbulkan dari berlakunya unsur pokok pernikahan. Sehingga pencatatan tidak dapat dijadikan sebagai rukun nikah.

Berdasarkan pandangan Siti Musdah Mulia tentang urgensi pencatatan nikah masuk dalam rukun nikah, peneliti beranggapan bahwa substansi pemikiran Musdah tentang pencatatan nikah adalah sebuah kewajiban yang harus dipenuhi. Sehingga, hakikatnya pencatatan nikah dipandang sebagai keabsahan yuridis, bukan keabsahan agama (fikih). Konsekuensi pernikahan yang dicatat adalah sah dalam artian mendapat kepastian hukum dan pengakuan dari negara. Dengan ungkapan lain, keabsahan pernikahan secara agama (normatif-teologis) adalah menekankan pada aspek sakralitas, sedangkan keabsahan perkawinan secara hukum (normatif-yuridis) adalah menekankan pada aspek legalitas. Oleh sebab itu, pencatatan tidak bisa dijadikan sebagai rukun nikah, karena rukun nikah erat kaitannya dengan keabsahan secara agama.

\section{Pemikiran Khoiruddin Nasution tentang Pencatatan Nikah}

Berdasarkan hasil pembacaan peneliti terhadap literatur-literatur dari Khoiruddin Nasution, lahirnya gagasan Khoiruddin Nasution tentang pencatatan nikah ini diperkirakan sejak beliau melakukan penelitian pada tahun 2001. Hasil penelitian tersebut pada akhirnya menjadi disertasi yang berjudul "Status Perempuan di Asia Tenggara: Studi Terhadap Perundang-undangan Perkawinan Muslim Kontemporer di Indonesia dan Malaysia." Penelitian tersebut difokuskan pada aspek pembaruan hukum keluarga, yakni poligami, pencatatan perkawinan, peranan wali dan kebebasan mempelai perempuan serta proses perceraian. ${ }^{39}$

Berbeda dengan Siti Musdah Mulia yang memberikan definisi perkawinan dengan menekankan pada aspek kontrak sosial (akad), dalam hal ini Khoiruddin Nasution tampak lebih menekankan aspek agama (khususnya Islam) dalam mendefinisikan arti sebuah perkawinan, sebagaimana dalam Alquran perkawinan merupakan ikatan yang kokoh dan melebihi dari ikatanikatan (transaksi) yang lain. Menurut peneliti konsep perkawinan yang dikemukakan oleh Khoiruddin Nasution sejalan dengan konsep perkawinan dalam UUP dan KHI. Perkawinan

\footnotetext{
${ }^{39}$ Khoiruddin Nasution, Status Wanita di Asia, h. 13-14.
} 
dalam UUP diartikan sebagai ikatan lahir batin antara seorang pria dan seorang wanita sebagai suami istri dengan tujuan membentuk keluarga atau rumah tangga yang bahagia dan kekal berdasarkan Ketuhanan Yang Maha Esa. ${ }^{40}$ Adapun perkawinan dalam Kompilasi Hukum Islam diartikan sebagai akad yang sangat kuat atau mis̄äqan galīzan untuk mentaati perintah Allah dan melaksanakannya merupakan ibadah. ${ }^{41}$ Dengan demikian, perkawinan memiliki dua sisi, yakni sebagai ikatan keperdataan karena merupakan akad (ikatan) antara mempelai laki-laki dan perempuan dan sebagai ikatan keagamaan karena merupakan syariat dari Allah dan anjuran untuk melakukannya. Sebagai ikatan keagamaan, perkawinan memiliki ketentuan-ketentuan yang harus dipenuhi. Ketentuan-ketentuan yang dimaksud adalah rukun dan syarat perkawinan.

Berkaitan dengan rukun dan syarat perkawinan, Khoiruddin Nasution menggangap tidak satupun ulama klasik memberikan definisi yang pasti dan jelas. Sehingga terjadi silang pendapat antara fuqaha (para ahli hukum Islam) dalam menyebutkan unsur mana yang menjadi rukun dan mana yang menjadi syarat. Oleh sebab itu, dapat dipastikan bahwa pada dasarnya rukun dan syarat perkawinan dalam kajian fikih merupakan hasil ijtihad, sehingga hasil ijtihad dalam menentukan mana rukun dan syarat perkawinan tersebut bersifat temporal (sesuai dengan konteksnya). ${ }^{42}$

Peneliti menilai pandangan Khoiruddin Nasution terhadap rukun dan syarat perkawinan yang didasari ketidaktegasan fuqaha (para ahli hukum Islam) dalam memberikan definisi syarat dan rukun perkawinan adalah dilihat dari sisi perbedaan pendapat dari fuqaha terhadap rukun dan syarat perkawinan itu sendiri. Padahal perbedaan tersebut menurut Amir Syarifuddin adalah disebabkan fuqaha (para ahli hukum Islam) berbeda dalam melihat fokus perkawinan. Sebagaimana Imam Syafi'i mengartikan perkawinan sebagai akad, sedangkan Imam Hanafi memandang perkawinan sebagai hubungan suami istri (wat $\left.{ }^{\prime} i\right) .{ }^{43}$ Oleh sebab itu, perbedaan fuqaha dalam menempatkan mana yang rukun dan mana yang syarat tidaklah bersifat substansial. Karena fuqaha (para ahli hukum Islam) sepakat bahwa unsur-unsur yang harus ada dalam perkawinan adalah akad perkawinan (ijab kabul), mempelai laki-laki dan perempuan, wali dan saksi yang menyaksikan akad perkawinan. ${ }^{44}$ Berkaitan dengan unsur-unsur tersebut, secara konkret pemerintah telah menetapkannya sebagai rukun nikah sebagaimana dalam KHI Pasal 14 menegaskan bahwa untuk melaksanakan perkawinan harus ada: 1) calon suami, 2) calon istri, 3) wali nikah, 4) dua orang saksi, 5) ijab kabul. ${ }^{45}$ Dengan demikian KHI tersebut memberikan kepastian hukum terhadap unsur-unsur yang menjadi penentu keabsahan suatu perkawinan. Hal ini sejalan dengan kaidah fikih,

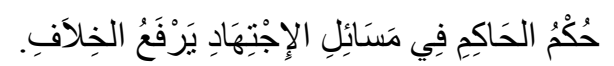

Artinya : Hukum yang diputuskan oleh hakim (pemerintah) dalam masalah-masalah ijtihad menghilangkan perbedaan pendapat. ${ }^{46}$

Pembahasan tentang pencatatan nikah dalam kitab-kitab fikih konvensional tidak ditemukan. Hanya saja terdapat konsep nikah siri dalam kitab al-Mudawwanah al-Kubra karangan Sahnun dan pembahasan tentang saksi yang oleh ulama lain menjadi sub bahasan

\footnotetext{
${ }^{40}$ Tim Permata Press, Undang-undang Perkawinan, h. 2.

${ }^{41}$ Departemen Agama RI, Kompilasi Hukum Islam, h. 14.

${ }^{42}$ Khoiruddin Nasution, Pencatatan Sebagai Syarat, h. 168.

${ }^{43}$ Wahbah az-Zuhailī, al-Fiqhu asy-Syafi'i al-Muyassar, h. 449-450.

${ }^{44}$ Amir Syarifuddin, Hukum Perkawinan Islam, h. 59.

${ }^{45}$ Departemen Agama RI, Kompilasi Hukum Islam, h. 18.

${ }^{46}$ A. Djazuli, Kaidah-kaidah Fikih, h. 154.
} 
tersendiri, oleh Sahnun hanya disinggung ketika membahas status hukum nikah siri. ${ }^{47}$ Hal inilah mengukuhkan argumentasi Khoiruddin Nasution bahwa fungsi pencatatan nikah memiliki kesamaan dengan fungsi saksi.

Khoiruddin Nasution berkesimpulan bahwa rukun atau syarat perkawinan adalah hasil pemikiran ulama (ijtihad). Sebagaimana kedudukan saksi dalam pernikahan terjadi silang pendapat antar fuqaha (para ahli hukum Islam). Adapun kedudukan saksi pernikahan menurut fuqaha (para ahli hukum Islam), sebagai berikut.

Imam Malik berpendapat saksi tidak termasuk rukun nikah, tetapi yang menjadi rukun adalah pengumuman. Konsekuensi dari pendapat Imam Malik yang menekankan pengumuman nikah, maka pernikahan yang diumumkan walaupun hanya kepada anak-anak dan orang gila nikah tersebut tetap sah. Hal ini berdasarkan pada hadis Rasulullah SAW yang menyuruh mengumumkan perkawinan dan membunyikan pukulan-pukulan gendang sebagai isyarat salah satu cara mengumumkan.

Imam Hanafi, Syafi'i dan Hambali menjadikan saksi sebagai unsur yang harus ada dalam pernikahan. Menurut as-Sarakhsi setidaknya ada dua argumentasi yang mendasari pendapat tersebut, yakni 1) hadis yang mengharuskan kehadiran empat unsur dalam akad nikah untuk sahnya pernikahan yaitu calon suami, wali dan dua orang saksi ${ }^{48}$, 2) asar ${ }^{6}$ Umar yang tidak mengakui keabsahan pernikahan yang hanya dihadiri oleh seorang saksi. Imam Hanafi berpendapat saksi tidak harus bersifat adil, sedangkan Imam Syafi'i saksi itu harus adil (berdasarkan hadis Rasulullah SAW tentang perkawinan harus dengan wali dan dua orang saksi yang adil). Adapun menurut Ibnu Qudamah dari Mazhab Hambali menyaratkan bahwa saksi pernikahan harus laki-laki, tidak boleh seorang żimmi, boleh orang buta dengan syarat benarbenar mengetahui suara orang melakukan akad. ${ }^{49}$

Berdasarkan penjelasan tentang kedudukan saksi di atas, secara substansial fuqaha (para ahli hukum Islam)sepakat mewajibkan eksistensi saksi dalam akad nikah. Hanya saja, Imam Malik terlihat lebih menekankan fungsi saksi sebagai sarana pengumuman. Namun, Imam Malik tetap berpandangan bahwa saksi menjadi syarat sah pernikahan, tetapi kalau sudah ada pengumuman telah terjadinya pernikahan, maka unsur kesaksian dapat ditunda pelaksanaannya (setelah selesai akad nikah) selama belum terjadi hubungan suami-istri. Sebagai jalan tengah mengenai kedudukan saksi, al-Kasani berpandangan bahwa saksi merupakan syarat sah pernikahan yang fungsinya untuk menyebarkan informasi pernikahan kepada masyarakat. ${ }^{50}$

Pencatatan nikah dijadikan Khoiruddin Nasution sebagai syarat sah atau rukun perkawinan ini didasari untuk mewujudkan tujuan dari perkawinan, yakni agar mencapai keluarga sakinah, mawaddah wa rahmah. Jika tidak dicatat besar kemungkinan malah sebaliknya. Rukun dan syarat perkawinan pada prinsipnya adalah alat untuk mencapai tujuan syariat. ${ }^{51}$ Sebagaimana yang telah dijelaskan sebelumnya, pencatatan nikah merupakan kontekstualisasi dari bentuk walimah, pengumuman dan saksi pernikahan. Hal ini disebabkan tuntutan zaman dan kebutuhan yang mendesak maka diperlukanlah pencatatan dalam pernikahan.

\footnotetext{
${ }^{47}$ Khoiruddin Nasution, Hukum Perdata (Keluarga), h. 321.

${ }^{48}$ Wahbah az-Zuhailī, al-Fiqhu al-Islāmī wa Adillatuhu, diterjemahkan oleh Abdul Hayyie al-Kattani dengan judul "Fiqh Islami wa Adillatuhu Jilid 9", Jakarta: Gema Insani, cet. ke-1, 2011, h. 74.

${ }^{49}$ Ibid., h. 322-331.

${ }^{50}$ Ibid., h. 330-333.

${ }^{51}$ Wawancara dengan Khoiruddin Nasution tanggal 09 Oktober 2016.
} 
Tujuan atau misi dari perkawinan adalah untuk membentuk keluarga sakinah, mawaddah wa rahmah yang didasarkan pada surah ar-Rum ayat 21. Adapun salah satu prinsip perkawinan untuk mencapai tujuan tersebut agar perkawinan menjadi tentram (sakinah) adalah harus mendapat pengakuan dan terjaminnya hak-hak dalam perkawinan. Dalam pelapisan ilmu hukum Islam, tujuan dan prinsip perkawinan merupakan norma abstrak. Tentunya untuk mewujudkan prinsip dan tujuan perkawinan tersebut diperlukan hukum konkret dalam artian hukum praktis sebagai tatacara dalam pernikahan. Oleh sebab itulah, fuqaha(para ahli hukum Islam) melakukan penalaran terhadap hukum praktis pernikahan. Dari hasil penalaran tersebut prinsip perkawinan untuk pengakuan dan penjaminan hak adalah dalam bentuk walimah, pengumuman dan saksi pernikahan. Bentuk pengakuan dan penjaminan hak pada masyarakat kultur lisan adalah dengan pengumuman. Sedangkan pengakuan dan penjaminan hak pada masyarakat kultur tulis adalah dengan pencatatan nikah dalam bentuk akta nikah.

Peneliti menilai pandangan Khoiruddin Nasution tentang pencatatan nikah sebagai rukun nikah lebih komprehensif daripada Siti Musdah Mulia. Hal ini disebabkan Khoiruddin Nasution telah melakukan sinkronisasi antar hadis tentang perlunya pengumuman, walimah dan saksi perkawinan yang pada asasnya sebagai bentuk pengakuan dan penjaminan hak pada masa Rasulullah SAW. Setelah mendapatkan substansi walimah, pengumuman dan saksi pernikahan, lalu disinkronkan dengan tujuan perkawinan. Karena pada dasarnya tujuan pernikahan akan sulit dicapai jika tidak diumumkan dan disaksikan. Adapun pada masa sekarang pencatatan merupakan salah satu sarana yang lebih efektif untuk mencapai tujuan perkawinan. Untuk lebih mudah memahami pencatatan nikah dalam pelapisan hukum perkawinan Islam ${ }^{52}$ ditunjukkan pada Gambar 1.

\section{Pelapisan Hukum Perkawinan Islam}

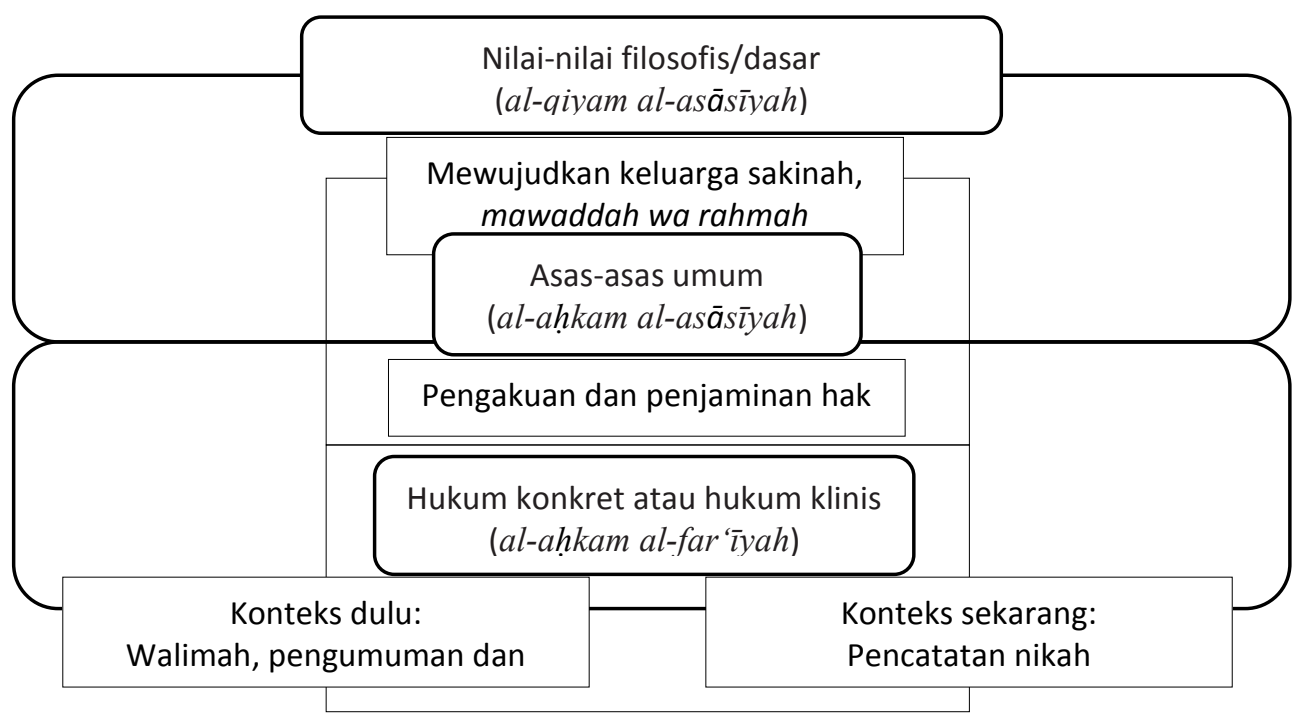

Gambar 1. Pelapisan hukum perkawinan Islam

Berdasarkan pelapisan hukum perkawinan Islam di atas, terdapat dua macam sinkronisasi, yakni sinkronisasi horizontal dan sinkronisasi vertikal. Bentuk sinkronisasi horizontal adalah

${ }^{52}$ Istilah pelapisan hukum perkawinan Islam ini dibuat peneliti dengan menyesuaikan konsep pelapisan hukum Islam milik Khoiruddin Nasution. 
antara pencatatan nikah dengan walimah, pengumuman dan saksi pernikahan memiliki kesamaan fungsi untuk pengakuan dan penjaminan hak. Sedangkan bentuk sinkronisasi vertikal adalah pencatatan nikah merupakan bentuk pengakuan dan penjaminan hak pada konteks masyarakat kultur tulis dan salah satu langkah efektif untuk mewujudkan tujuan pernikahan yang sakinah, mawaddah wa rahmah.

Peneliti menilai pandangan Khoiruddin Nasution tentang pencatatan nikah sebagai syarat dan/atau rukun nikah lebih menekankan konteks (sosio-historis) hadis tentang walimah, pengumuman dan saksi daripada teks hadis itu sendiri. Sehingga, dengan adanya perubahan dan perkembangan zaman serta tuntutan yang mendesak, maka pencatatan nikah menjadi rukun nikah sebagaimana kedudukan saksi menjadi rukun dalam pernikahan. Padahal secara tekstual hadis tentang walimah dan pengumuman jumhur ulama telah sepakat hukumnya sunnah muakkad dan bukan menjadi rukun pernikahan, adapun secara kontekstual walimah dan pengumuman memiliki fungsi untuk mengukuhkan atau memperkuat kehadiran saksi. ${ }^{53}$ Sedangkan, secara tekstual hadis tentang saksi adalah sebagai syarat sahnya penikahan, adapun secara kontekstual saksi juga memiliki fungsi sebagai alat bukti (bayyinah syar'iyah) ${ }^{54}$ Oleh sebab itu, menurut hemat peneliti kedudukan pencatatan nikah jika dikaitkan pada konteks walimah, pengumuman dan saksi lebih tepatnya hanyalah sebagai penguat kesaksian dan alat bukti pernikahan, bukan sebagai rukun nikah. Karena, jika pencatatan nikah dijadikan sebagai rukun nikah dengan alasan perubahan dan perkembangan zaman, maka rukun nikah tentunya juga akan selalu berubah mengikuti perubahan dan perkembangan zaman.

Pada dasarnya rukun dan syarat pernikahan merupakan produk pemikiran (fikih) fuqaha. Namun bukan berarti fikih tersebut hasil rekayasa fuqaha, karena mereka telah berupaya semaksimal mungkin menggali hukum dari dalil-dalil syara' (Alquran dan Hadis) yang terperinci. Bahkan secara tegas diungkapkan oleh 'Umar Sulayman al-Așqar dalam bukunya Tarikh al-Fiqh al-Islämi yang dikutip oleh Nirwan Syafrin, "bahwa fikih ada kalanya bisa menjadi syariat yaitu ketika ijtihad yang dilakukan ulama tersebut mengenai sasaran sesuai dengan ketetapan Allah. Tapi ada kalanya ijtihad juga salah, maka ketika itu fikih tetap sebagai fikih tidak berubah menjadi syariat." ${ }^{55}$

Pencatatan nikah dalam akad perkawinan adalah untuk memperkuat persaksian dalam pernikahan. Saksi dalam pernikahan selain berfungsi sebagai penentu keabsahan pernikahan juga berfungsi untuk menghindari dari fitnah dan pengingkaran oleh salah satu pihak bagi suami-istri, namun ditakutkan ingatan saksi yang bisa lupa atau bahkan meninggal dunia, maka untuk menghindari kejadian tersebut adalah dengan melakukan pencatatan nikah. Selain itu pencatatan nikah juga berfungsi untuk memastikan terpenuhi atau tidaknya rukun dan syarat perkawinan, sebagaimana dalam Pasal 6 ayat (1) Peraturan Pemerintah No. 9 Tahun 1975 tentang UUP menegaskan, "Pegawai Pencatat yang menerima pemberitahuan kehendak melangsungkan perkawinan, meneliti apakah syarat-syarat perkawinan telah dipenuhi dan apakah tidak terdapat

${ }^{53}$ Amiur Nuruddin, Hukum Keluarga Islam,h. 120-121.

${ }^{54}$ Menurut Ibnu Rusyd bukti-bukti dalam peradilan ada empat hal, yakni kesaksian, sumpah, penolakan sumpah dan pengakuan. Adapun menurut Sayyid Sabiq dalam hukum pembuktian ada empat metode penetapan dakwaan, yakni pengakuan, kesaksian, sumpah dan dokumen resmi. Lihat Ibnu Rusyd, Bidayah al-Mujtahid, h. 725. Lihat juga Sayyid Sabiq, Fiqhu as-Sunnah, diterjemahkan oleh Asep Sobari dkk, dengan judul "Fiqih Sunnah Sayyid Sabiq Jilid 3", Jakarta: Al-I'tishom, cet. ke-6, 2015, h. 527.

${ }^{55}$ Nirwan Syafrin, "Kritik Terhadap Paham Liberalisasi Syariat Islam", Jurnal Tsaqafah, Vol. 5, No. 1, 2008, h. 63. 
halangan perkawinan menurut Undang-Undang." ${ }^{56}$ Selanjutnya, pada Pasal 6 ayat (2) KHI yang menegaskan bahwa, "Perkawinan yang dilakukan di luar pengawasan Pegawai Pencatat Nikah tidak mempunyai kekuatan hukum", jika dihubungkan dengan Pasal 7 ayat (1) KHI, maka terlihat jelas bahwa substansi dari kata "tidak memiliki kekuatan hukum" bukan berarti pernikahan tidak sah, akan tetapi "tidak bisa dibuktikan di hadapan hukum". Hal ini disebabkan, KHI menegaskan bahwa pembuktian pernikahan bagi umat Islam "hanya dengan Akta Nikah yang dibuat oleh PPN. ${ }^{57}$

Akta dalam hukum perdata merupakan salah satu alat bukti tertulis. Pada Buku keempat Bab I Pasal 1865 KUHPer dinyatakan bahwa tujuan diadakannya alat bukti adalah sebagai berikut:

1) Sebagai dalil bahwa seseorang mempunyai sesuatu hak.

2) Untuk meneguhkan dan menguatkan bahwa seseorang mempunyai hak.

3) Untuk membantah atau menyatakan ketidakbenaran bahwa orang lain memiliki hak.

4) Untuk menunjukkan dan menyatakan bahwa telah terdapat suatu keadaan atau telah terjadi suatu peristiwa. ${ }^{58}$

Menurut hemat peneliti, pencatatan nikah bukanlah menjadi penentu sah atau tidaknya suatu perkawinan, hanya saja keberadaan pencatatan nikah yang merupakan suatu keterangan tertulis tentang akad penikahan secara hukum memegang peranan yang sangat penting. Urgensi pencatatan nikah adalah untuk mempertahankan dan melindungi hak-hak suami-istri akibat dari pernikahan yang sah. Selain itu, dengan melakukan pencatatan nikah tersebut, negara akan mengakui keabsahan dari adanya suatu peristiwa perkawinan. Pentingnya akta nikah sebagai alat bukti adanya sebuah perkawinan, sejalan dengan kaidah fikih,

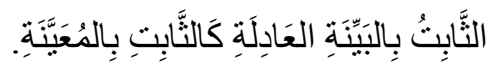

Artinya: Apa yang ditetapkan dengan bukti-bukti yang adil seperti yang ditetapkan berdasarkan kenyataan. ${ }^{59}$

Berdasarkan kaidah fikih di atas, akta nikah merupakan sebuah bukti tertulis yang dibuat oleh KUA sebagai dalil kenyataan bahwa perkawinan itu memang benar-benar ada dan sah secara hukum. Dengan demikian, pernikahan yang telah dicatat menjadi pernikahan yang legal di hadapan hukum.

\section{Relevansi Pemikiran Siti Musdah Mulia dan Khoiruddin Nasution tentang Urgensi Pencatatan Nikah Masuk dalam Rukun Nikah pada Konteks Sekarang}

Pada mulanya syari'at Islam baik dalam Alquran maupun hadis tidak mengatur secara konkret tentang adanya pencatatan perkawinan. Namun dalam hal muamalah (mudāyanah) yang dalam situasi tertentu diperintahkan untuk mencatatnya. Seiring perkembangan zaman dengan berbagai pertimbangan kemaslahatan, sehingga pencatatan nikah merupakan keniscayaan dan bahkan pencatatan nikah yang oleh Siti Musdah Mulia dan Khoiruddin Nasution mencoba meningkatkan grade-nya sebagai rukun nikah. Untuk menemukan relevansi pemikiran Siti Musdah Mulia dan Khoiruddin Nasution tersebut pada konteks sekarang khususnya di Indonesia maka harus dilihat dari beberapa landasan. Adapun landasan tersebut adalah sebagai berikut:

\footnotetext{
${ }^{56}$ Peraturan Pemerintah No. 9 tahun 1975 tentang Pelaksanaan UUP.

${ }^{57}$ Departemen Agama RI, Kompilasi Hukum Islam, h. 15.

${ }^{58}$ Seri Hukum dan Perundangan, h. 455.

${ }^{59}$ A. Djazuli, Kaidah-kaidah Fikih, h. 161.
} 


\section{a. Landasan Filosofis}

Perkawinan atau pernikahan menurut hukum Islam yang sesuai dengan landasan filosofis adalah berdasarkan Pancasila, khususnya sila pertama, yakni Ketuhanan Yang Maha Esa. Landasan filosofis ini dipertegas dalam Pasal 2 KHI yang berisi: 1) Perkawinan semata-mata menaati perintah Allah, 2) Melaksanakan perkawinan adalah ibadah dan 3) Ikatan perkawinan bersifat mïsāqan galizzan (ikatan yang kokoh) ${ }^{60}$ Berdasarkan landasan filosofis perkawinan tersebut, dapat ditarik suatu substansi bahwa esensi perkawinan Islam adalah meliputi aspek akidah, ibadah dan muamalah. Ketiga aspek tersebut sangat mewarnai dalam pernikahan, oleh sebab itu pernikahan merupakan hal yang sangat sakral. Selain itu, pernikahan juga sangat dianjurkan oleh Rasulullah SAW dan merupakan separuh bagian dari agama, sebagaimana sabda Rasulullah SAW yang artinya sebagai berikut:

Artinya: "Diriwayatkan dari Anas bin Malik ra., ia berkata, 'Ada tiga orang datang ke rumah istri-istri Rasulullah SAW, dan menanyakan tentang ibadah Rasulullah SAW. Ketika mereka diberi tahu, mereka menganggap ibadah mereka sedikit.' Mereka berkata, 'Di mana kita dari Rasulullah SAW padahal beliau sudah Allah ampuni dosa-dosanya; yang lalu ataupun yang akan datang.' Salah seorang dari mereka berkata, 'Kalau begitu, saya akan solat sepanjang malam selamanya.' Yang lain berkata, 'Saya akan puasa sepanjang tahun dan tidak akan berbuka.' Dan yang terakhir berkata, 'Kalau saya akan menjauhi wanita dan tidak akan menikah selamanya.' Kemudian Rasulullah SAW datang (menemui mereka) dan bersabda, 'Kalian yang mengatakan begini, begini? Demi Allah, sesungguhnya akulah orang yang paling takut kepada Allah dan paling bertakwa, akan tetapi aku puasa dan juga buka puasa, aku solat malam, tapi juga tidur, dan aku menikahi wanita. Barangsiapa yang tidak suka sunnahku maka ia tidak termasuk golonganku." (HR. Bukhari). ${ }^{61}$

Artinya: "Telah mengabarkan kepada kami Ahmad ar-Razzāz, telah menceritakan kepada kami 'Usman bin Ahmad bin 'Abdillah ad-Daqqāq, telah menceritakan kepada kami Yahya bin Abi Țālib, telah mengabarkan kepada kami Ya'qub bin Ishaq alHaḍramī, telah menceritakan kepada kami al-Khalil bin Murrah, dari Yazid arRaqasȳ̄, dari Anas bin Malik ra., berkata: Rasulullah SAW bersabda, 'Jika seorang hamba menikah, maka ia telah menyempurnakan separuh agamanya. Maka bertakwalah pada Allah pada separuh yang lainnya."62

Perkawinan merupakan jalan yang diridai Allah SWT untuk menghalalkan hubungan suami-istri dalam rangka mewujudkan kehidupan keluarga yang bahagia dan diliputi rasa ketentraman serta kasih sayang. ${ }^{63}$ Pernikahan yang sah menurut hukum Islam (fikih) adalah yang telah memenuhi rukun dan syarat nikah. Sebagaimana pada penjelasan sebelumnya, bahwa rukun adalah segala hal yang harus ada dan merupakan hakikat/inti perkawinan. Sedangkan syarat adalah segala hal yang harus ada, akan tetapi bukan merupakan hakikat/inti perkawinan. Rukun pernikahan yang telah disepakati para ulama adalah adanya

${ }^{60}$ Departemen Agama RI, Kompilasi Hukum Islam, h. 14.

${ }^{61} Z a i n u d d i n$ Ahmad bin AbdullathifAl-Zabidy, Mukhtașar Șaḥị̣ Al-Bukhari, h. 1035.

${ }^{62}$ HR. Al-Khatib al-Bagdadi No. 856 dalam Kitab Muwaḍḍ̣ Auham al-Jami' wa al-Tafriq. Lihat www.islamweb.net

${ }^{63}$ Titik Triwulan Tutik, Hukum Perdata dalam Sistem Hukum Nasional, Jakarta: Kencana, cet. ke-1, 2008 , h. 99. 
calon suami, calon istri, șigah (ijab dan kabul), dua orang saksi dan wali. ${ }^{64}$ Jika suatu akad pernikahan tidak terpenuhi beberapa rukun dan syarat, maka pernikahan tersebut tidak sah. Tidak sahnya suatu pernikahan disebabkan tidak dipenuhinya salah satu di antara rukun nikah disebut pernikahan yang batal. Sedangkan, jika tidak dipenuhi salah satu syarat nikah disebut pernikahan yang fasid. ${ }^{65}$ Konsekuensi logis dari ikatan pernikahan yang sah adalah halalnya hubungan antara suami-istri dan lahirnya hak dan kewajiban di antara suami-istri, yakni hak istri untuk dipenuhi dan sebaliknya serta hak bersama yang harus ditanggung bersama. Untuk menjamin hak dan kewajiban yang timbul dari akibat pernikahan yang sah maka setiap perkawinan harus dilakukan pencatatan.

Pencatatan nikah secara filosofis adalah untuk mewujudkan ketertiban dan kepastian hukum $^{66}$ baik bagi yang bersangkutan maupun orang lain dan masyarakat. Berkaitan dengan landasan filosofis pernikahan dan pencatatan nikah, Zainuddin Ali telah memisahkan antara keabsahan perkawinan dan pencatatan nikah menjadi dua asas, yakni 1) asas keabsahan perkawinan didasarkan pada hukum agama dan kepercayaan bagi pihak yang melaksanakan perkawinan, dan 2) asas pencatatan perkawinan didasarkan untuk mempermudah mengetahui manusia yang sudah menikah atau melakukan ikatan perkawinan. ${ }^{67}$

\section{b. Landasan Yuridis}

Rumusan perkawinan yang sah dan pencatatan perkawinan disebutkan dalam satu pasal pada Pasal 2 UUP. Pasal 2 ayat (1) UUP menyatakan, "Perkawinan adalah sah apabila dilakukan menurut hukum masing-masing agamanya dan kepercayaannya itu."68 Pasal ini dipertegas dalam penjelasan Pasal 2 UUP, yang menyatakan, "Dengan perumusan pada Pasal 2 ayat (1) ini, tidak ada perkawinan di luar hukum masing-masing agamanya dan kepercayaannya itu termasuk ketentuan perundang-undangan yang berlaku bagi golongan agamanya dan kepercayaannya itu sepanjang tidak bertentangan atau tidak ditentukan lain dalam Undang-Undang ini." 69 Dengan demikian, bagi penganut agama atau kepercayaan suatu agama, maka sahnya pernikahan mereka oleh UUP telah diserahkan kepada hukum agamanya dan kepercayaannya itu. Hubunganya dengan hukum Islam tentang rumusan pernikahan yang sah dalam Pasal 2 ayat (1) UUP ini merupakan jaminan atau berlakunya hukum Islam bagi umat Islam yang melangsungkan pernikahannya. Hukum pernikahan Islam yang dimaksud dalam Pasal 2 ayat (1) itu menurut Hazairin yang dikutip oleh Taufiqurrohman Syahuri, adalah hukum Islam bukan menurut teori resepsi yang menggantungkan berlakunya hukum Islam pada hukum adat, melainkan hukum Islam

\footnotetext{
${ }^{64}$ Slamet Abidin dan Aminudin, Fiqih Munakahat 1, Bandung: CV Pustaka Setia, c. ke-1, 1999, h. 64-68. Lihat juga Abdul Rahman, Figh Munakahat, h. 46-48.

${ }^{65}$ Abdul Wahhab Khallaf, IIm Ușūl al-Fiqh, h. 176.

${ }^{66}$ Kepastian hukum menurut Sudikno Mertokusumo adalah hal yang sangat penting, karena masyarakat mengharapkan adanya kepastian hukum karena dengan adanya kepastian hukum, masyarakat akan lebih tertib. Hukum bertugas menciptakan kepastian hukum dan berfungsi untuk ketertiban masyarakat. Artinya, tanpa kepastian hukum orang tidak tau apa yang harus diperbuatnya sehingga akhirnya timbul keresahan. Lihat Sudikno Mertokusumo, Mengenal Hukum (Suatu Pengantar), Jakarta: Liberty, 1988, h. 136.

${ }^{67}$ Zainuddin Ali, Hukum Perdata Islam, h. 6-7.

${ }^{68}$ Tim Permata Press, Undang-undang Perkawinan, h. 2.

${ }^{69}$ Ibid., h. 30.
} 
menurut Pasal 29 UUD 1945 yang memuat kewajiban negara untuk menjalankan hukum setiap agama yang ber-Ketuhanan Yang Maha Esa. Dengan demikian bagi umat Islam ketentuan mengenai terlaksananya akad nikah dengan syarat-syarat dan rukunnya tetap mempunyai kedudukan yang menentukan sah atau tidak sahnya suatu pernikahan. ${ }^{70}$

Perkawinan bagi umat Islam yang telah dilakukan sesuai dengan ketentuan agama berdasarkan fikih, maka berdasarkan Pasal 2 ayat (2) UUP perkawinan tersebut harus dicatatkan menurut peraturan perundang-undangan yang berlaku. ${ }^{71}$ Pencatatan perkawinan bagi orang-orang yang menganut agama dan kepercayaannya itu selain agama Islam dilakukan oleh pegawai pencatat perkawinan pada Kantor Catatan Sipil. Sedangkan bagi orang-orang yang beragama Islam, pencatatan perkawinan dilakukan oleh pegawai pencatat nikah di Kantor Urusan Agama (KUA) sesuai dengan Undang-Undang Nomor 32 Tahun 1954 Tentang Pencatatan Nikah, Talak dan Rujuk. ${ }^{72}$

Berdasarkan uraian di atas, ketentuan sahnya pernikahan seperti yang dimaksud dalam Pasal 2 ayat (1) UUP itu dari segi Hukum Islam sudah memadai, karena akad nikah sebagai penentu sahnya perkawinan dijamin kelangsungannya. Namun sahnya pernikahan menurut Pasal 2 ayat (1) itu masih dituntut oleh ayat (2) yakni harus dicatatkan. Dengan demikian, pencatatan pernikahan yang dilakukan oleh petugas pencatat perkawinan hanyalah untuk kepentingan administrasi negara sebagai bukti bahwa pernikahan benar-benar telah terjadi, bukan sebagai faktor penentu sah atau tidaknya suatu pernikahan. Walaupun pencatatan nikah bukan syarat sah pernikahan dan hanya sekadar kewajiban administrasi ${ }^{73}$, sebagaimana yang dimaksudkan Pasal 5 ayat (1) KHI, "Agar terjamin ketertiban perkawinan bagi masyarakat Islam setiap perkawinan harus dicatat." 74 Namun, implikasi dari pencatatan nikah dalam praktiknya bermanfaat sangat positif, terciptanya ketertiban yang berkaitan dengan administratif kenegaraan diharapkan akan mengarah kepada terciptanya ketertiban sosial kemasyarakatan, peristiwa-peristiwa pernikahan di Indonesia dapat dikontrol sehingga tidak ada pihak-pihak (khususnya istri dan anak) yang dirugikan.

Pencatatan nikah tidak hanya diatur dalam peraturan perundang-undangan di Indonesia, namun juga diatur oleh beberapa negara lain. Di Pakistan misalnya, pemerintah telah membuat sebuah aturan yang menyatakan, jika aturan pencatatan pernikahan tidak ditaati maka pihak-pihak yang terlibat dalam akad nikah itu secara pasti dikenakan hukuman penjara atau denda. Namun, aturan di Pakistan menegaskan bahwa pernikahan tidak tercatat dianggap sah secara agama. Malaysia senada dengan Pakistan tentang aturan pencatatan, dan menegaskan bahwa pencatatan hanya merupakan syarat administrasi dan pernikahan tidak

\footnotetext{
${ }^{70}$ Taufiqurrohman Syahuri, Legislasi Hukum Perkawinan di Indonesia: Pro-Kontra Pembentukannya Hingga Putusan Mahkamah Konstitusi, Jakarta: Kencana Prenada Media Group, cet. ke-1, 2013, h.167-171.

${ }^{71}$ Tim Permata Press, Undang-undang Perkawinan, h. 2.

${ }^{72}$ Taufiqurrohman Syahuri, Legislasi Hukum Perkawinan, h. 169.

${ }^{73}$ Dalam hukum administrasi, pencatatan nikah merupakan kewajiban administratif dan bukan penentu keabsahan suatu pernikahan. Sebagaimana pada Pasal 34 ayat (1) UU Administrasi Kependudukan menegaskan bahwa, "Perkawinan yang sah berdasarkan ketentuan Peraturan Perundang-undangan wajib dilaporkan oleh Penduduk kepada Instansi Pelaksana di tempat terjadinya perkawinan paling lambat 60 (enam puluh) hari sejak tanggal perkawinan." Lihat Tim Permata Press, Undang-Undang Perkawinan, h. 59.

${ }^{74}$ Departemen Agama RI, Kompilasi Hukum Islam, h. 15.
} 
tercatat dianggap sah. Di Singapura, sanksi pidana diterapkan pada mereka yang tidak mendaftarkan perkawinan mereka. Maroko juga menuntut pencatatan pernikahan sebagai persyaratan administratif, sebagaimana Pakistan dan Singapura. Namun, Maroko tidak menetapkan sanksi yang tegas terhadap mereka yang tidak menaati aturan itu. ${ }^{75}$

Menurut peneliti, pencatatan nikah di berbagai negara yang telah dipaparkan di atas tidak sedikitpun mempengaruhi keabsahan suatu perkawinan. Ketentuan pencatatan nikah hanyalah bersifat administratif. Walaupun hanya bersifat administratif, akan tetapi yang melanggar aturan pencatatan nikah akan dikenakan hukuman penjara atau denda.

Pentingnya suatu pencatatan dalam pernikahan yang merupakan sarana agar terjaminnya kepastian hukum dalam pernikahan, dalam hal ini Syekh Jaad al-Haq Ali Jaad al-Haq yang dikutip oleh Satria Effendi M. Zein, membagi ketentuan yang mengatur pernikahan kepada dua kategori:

a) Peraturan syara', yaitu peraturan yang menentukan sah atau tidak sahnya sebuah pernikahan. Peraturan ini adalah peraturan yang ditetapkan oleh syariat Islam seperti yang telah dirumuskan oleh para pakarnya dalam buku-buku fikih dari berbagai mazhab.

b) Peraturan yang bersifat tawsiqi, yaitu peraturan tambahan yang bermaksud agar pernikahan di kalangan umat Islam tidak liar, tetapi tercatat dengan memakai surat Akta Nikah secara resmi yang dikeluarkan oleh pihak yang berwenang. Kegunaan pencatatan nikah adalah agar sebuah lembaga perkawinan yang mempunyai tempat yang sangat penting dan strategi dalam masyarakat Islam bisa dilindungi dari adanya upaya-upaya negatif dari pihak-pihak yang tidak bertanggung jawab. ${ }^{76}$

Senada dengan pendapat Syekh Jaad al-Haq Ali Jaad al-Haq di atas, Wahbah azZuhailīyang dikutip oleh Satria Effendi M. Zein, secara tegas membagi syarat nikah menjadi syarat syar'i dan syarat tawsiqi. Syarat syar'i, maksudnya suatu syarat di mana keabsahan suatu pernikahan adalah terpenuhinya syarat dan rukun yang telah ditetapkan oleh ketentuan agama. Sedangkan syarat tawsiqi merupakan sesuatu yang telah dirumuskan yang kemudian menjadi bukti kebenaran suatu tindakan sebagai upaya antisipasi adanya ketidakjelasan di kemudian hari. ${ }^{77}$

\section{c. Landasan Sosiologis}

Karakteristik masyarakat Indonesia merupakan masyarakat multikultural dan multireligius. Hal ini terbukti di Indonesia memiliki banyak suku bangsa yang masingmasing mempunyai struktur budaya yang berbeda-beda. Perbedaan ini dapat dilihat dari perbedaan bahasa, suku, ras, warna kulit, adat istiadat dan agama. Dua hal yang terakhir disebut sangat mempengaruhi dalam tata pelaksanaan perkawinan di Indonesia.

Perkawinan yang sah di Indonesia adalah sesuai dengan aturan hukum yang berlaku. Perkawinan yang sah menurut aturan agama adalah perkawinan yang telah memenuhi tata-

\footnotetext{
${ }^{75}$ Asep Saepudin Jahar dkk, Hukum Keluarga, Pidana \& Bisnis (Kajian Perundang-Undangan Indonesia, Fikih dan Hukum Internasional), Jakarta: Kencana Prenadamedia Group, cet. ke-1, 2013, H. 28.

${ }^{76}$ Satri Effendi M. Zein, Problematika Hukum Keluarga Islam Kontemporer, Jakarta: Kencana, cet. ke-1, 2004, h. 33.

${ }^{77}$ Ibid., h.34-35.
} 
tertib hukum agama, begitu pula perkawinan yang sah menurut hukum adat adalah perkawinan yang telah memenuhi tata-tertib hukum adat. Sahnya perkawinan menurut hukum adat bagi masyarakat hukum adat di Indonesia pada umumnya tergantung pada agama yang dianut masyarakat adat bersangkutan. Misalnya, menurut hukum Islam perkawinan yang sah adalah perkawinan yang dalam pelaksanaannya telah memenuhi unsurunsur nikah, seperti akad nikah, mempelai pengantin (laki-laki dan perempuan), wali dan saksi.

Menurut hukum Kristen/Katolik perkawinan yang sah apabila sudah memenuhi syaratsyarat yang telah ditentukan dan perkawinannya dilaksanakan di hadapan Pastur yang dihadiri oleh dua orang saksi. Selain itu, untuk dapat disahkan perkawinan itu maka kedua mempelai harus sudah dibaptis, ada kesepakatan antara kedua mempelai, tidak ada kekeliruan tentang identitas mempelai, tidak ada paksaan, telah berumur 16 (enam belas) tahun bagi pria dan telah berumur 14 (empat belas) tahun bagi wanita dan salah satu atau kedua calon suami-istri tidak terikat perkawinan sebelumnya.

Menurut hukum agama Hindu perkawinan yang sah adalah apabila dilakukan di hadapan Brahmana atau pendeta atau pejabat agama yang memenuhi syarat untuk melakukan perbuatan itu. Syarat lain untuk sahnya perkawinan menurut hukum Hindu adalah harus dilaksanakan berdasarkan hukum Hindu, jadi kedua calon suami-istri harus menganut agama Hindu. Jika berbeda agama antara calon suami-istri maka perkawinan itu tidak dapat disahkan.

Menurut hukum agama Budha perkawinan adalah sah apabila dilakukan menurut Hukum Perkawinan Agama Budha Indonesia (HPAB Pasal 2). Untuk sahnya perkawinan maka para calon suami-istri harus memenuhi syarat yang ditentukan dalam Pasal 4-7 HPAB 1977. Tempat upacara perkawinan yang sah adalah di Vihara atau Cetya atau di depan Altar Suci Sang Budha/Bodhisatwa setelah diresmikan dengan memanjatkan Paritta-paritta, Vandana, Trisarana, Pancasila dan Puja. Dengan demikian, sahnya perkawinan adalah telah dilaksanakan menurut tata-tertib masing-masing hukum agama. Namun, dalam perkawinan adat walaupun sudah sah menurut hukum agama, perlu dilaksanakan upacara perkawinan adat yang sudah mentradisi pada tiap-tiap daerah. ${ }^{78}$

Eksistensi pencatatan nikah di Indonesia secara sosiologis diakui keberadaannya (pencatatan nikah) yang dapat dilihat dari dua perspektif, yakni pengakuan dari masyarakat dan kebijakan dari pemerintah. Pertama, pencatatan nikah diakui oleh masyarakat karena secara sosiologis memiliki banyak kegunaan (manfaat) khususnya bagi istri dan anak. Bagi istri manfaat pencatatan nikah adalah hak nafkah, hak waris dan hak harta gono-gini lebih terlindungi. Bagi anak manfaat pencatatan nikah adalah status anak jadi lebih jelas, yang berkaitan dengan harta seperti hak nafkah, hak waris dan juga hak perwalian menjadi lebih terjamin. Selain itu, dengan pencatatan nikah maka akan diterbitkan sebuah buku nikah sebagai bukti autentik bahwa pernikahan tersebut telah didaftarkan secara resmi di hadapan pegawai pencatat nikah. Dengan memiliki buku nikah, hal-hal yang berkaitan dengan kepentingan pembuatan Kartu Tanda Penduduk (KTP), Kartu Kelurga (KK), Pasport, Akta

\footnotetext{
${ }^{78}$ Hilman Hadikusuma, Hukum Perkawinan Indonesia, h. 25-31.
} 
Kelahiran, atau bahkan yang berkaitan dengan politik yaitu berhaknya memberikan suara atau dipilih pada pemilihan umum akan lebih mudah dilayani, ketimbang yang tidak memiliki buku nikah. Semua itu karena adanya bukti pernikahan berupa buku nikah yang akhirnya dapat membuat KTP dan KK, sementara untuk membuat akta kelahiran anak, atau pasport diharuskan adanya KTP, KK dan buku nikah. Begitu pentingnya buku nikah yang didapat melalui pencatatan nikah ini diibaratkan seperti Surat Izin Mengemudi (SIM) bagi pengendara kendaraan bermotor. Bagi pengendara yang memiliki SIM akan merasa aman berkendaraan di jalan tanpa ada perasaan khawatir dikenai tilang oleh Polantas. Demikian halnya bagi pasangan suami-istri yang memiliki buku nikah akan merasa aman dan tenteram dalam kehidupan rumah tangganya tanpa ada perasaan khawatir akan dirazia oleh Satpol PP apabila menginap di hotel atau digrebeg oleh massa karena dicurigai kumpul kebo dan sebagainya. Hal ini sejalan dengan teori kegunaan hukum (utility theory) dari Jeremy Bentham yang membahasakan hukum harus berguna bagi individu masyarakat untuk mencapai kebahagian sebesar-besarnya (greatest happines principle). ${ }^{79} \mathrm{Kedua}$, pencatatan nikah secara sosiologis juga merupakan bentuk kebijakan dari pemerintah agar pernikahan menjadi lebih tertib. Pencatatan nikah diperlukan sebagai perlindungan negara (pemerintah) kepada pihak-pihak dalam pernikahan dan untuk menghindari penerapan hukum agama secara sepotong-sepotong untuk melegitimasi sebuah pernikahan, sementara kehidupan rumah tangga pascapernikahan tidak sejalan dengan misi utama atau tujuan pernikahan untuk mencapai keluarga sakinah, mawaddah wa rahmah. Adanya penelantaran kepada istri dan anak, kekerasan dalam rumah tangga, fenomena kawin kontrak, istri simpanan, poligami tanpa sepengetahuan istri sebelumnya dan lain sebagainya adalah bukti tidak adanya konsistensi penerapan tujuan pernikahan secara utuh. Hal ini sejalan dengan teori dari Roscue Pound yang membahasakan hukum sebagai sarana untuk merekayasa sosial (law as a tool of social engineering), berkaitan kebijakan pemerintah tentang pencatatan nikah adalah sebagai alat untuk merancang masa depan masyarakat yang dijamin akan perlindungan hukum, kepastian hukum dan jaminan akan ketertiban dalam kehidupan. ${ }^{80}$

Menurut peneliti, keberlakuan pencatatan nikah secara sosiologis dalam perspektif pengakuan masyarakat adalah mempunyai banyak manfaat. Adapun dalam perspektif kebijakan pemerintah adalah sebagai alat atau sarana pemelihara ketertiban dan pembaruan masyarakat di bidang pernikahan. Dengan demikian, pencatatan nikah secara sosiologis bukanlah penentu sah atau tidaknya suatu pernikahan, karena keabsahan pernikahan adalah wilayah agama (khususnya Islam) yang sesuai dengan ketentuan yang telah disepakati oleh jumhur ulama. Untuk lebih memudahkan dalam memahami perbedaan antara rukun nikah dan pencatatan nikah yang ditinjau secara filosofis, yuridis dan sosiologis, lihatlah tabel di bawah ini.

\footnotetext{
${ }^{79}$ Donald Albert Rumokoy dan Frans Maramis, Pengantar Ilmu Hukum, h. 34. Lihat juga Sabian Utsman, Dasar-dasar Sosiologi Hukum, Yogyakarta: Pustaka Pelajar, cet. ke-1, 2009, h. 153.

${ }^{80}$ Soerjono Soekanto, Pokok-pokok Sosiologi Hukum, Jakarta: PT RajaGrafindo Persada, cet. ke-14, 2004, h. 135. Lihat jugaMunir Fuady, Teori-Teori Besar (Grand Theory) dalam Hukum, Jakarta: Kencana Prenada Media Group, cet. ke-1, 2013, h. 247.
} 
Menurut peneliti, dengan melihat kondisi masyarakat, hukum, norma-norma dan sosialkultural yang berkembang di masyarakat Indonesia saat ini maka pemikiran Siti Musdah Mulia dan Khoiruddin Nasution tentang pencatatan nikah sebagai rukun nikah yang ditinjau secara filosofis, yuridis dan sosiologis dapat dikatakan tidak relevan. Sebab, secara filosofis pencatatan nikah adalah untuk mewujudkan ketertiban dan kepastian hukum baik bagi yang bersangkutan maupun orang lain dan masyarakat. Secara yuridis pencatatan nikah adalah untuk ketertiban administrasi dan sebagai bukti autentik dalam suatu perkawinan. Secara sosiologis pencatatan nikah dalam perspektif pengakuan masyarakat adalah mempunyai banyak manfaat dan dalam perspektif kebijakan pemerintah adalah sebagai alat atau sarana pemelihara ketertiban dan pembaruan masyarakat di bidang pernikahan. Hal ini menunjukkan bahwa pencatatan nikah baik secara filosofis, yuridis dan sosiologis bukanlah penentu keabsahan dalam pernikahan. Sehingga, pencatatan tidak dapat dijadikan sebagai rukun nikah.

\section{Kesimpulan}

Berdasarkan hasil pembahasan dan analisis terhadap pemikiran Siti Musdah Mulia dan Khoiruddin Nasution tentang urgensi pencatatan nikah masuk dalam rukun nikah, maka dapat ditarik beberapa kesimpulan sebagai berikut:

1. Pemikiran Siti Musdah Mulia tentang urgensi pencatatan nikah masuk dalam rukun nikah karena banyak dampak mudarat yang ditimbulkan akibat pernikahan siri/bawah tangan. Dampak mudarat tersebut lebih banyak dirasakan oleh kaum perempuan dan anak ketimbang laki-laki. Oleh sebab itu, Siti Musdah Mulia menjadikan pencatatan nikah sebagai rukun nikah tidak lain adalah untuk memberikan proteksi atau perlindungan hukum terhadap istri dan anak.

2. Pemikiran Khoiruddin Nasution tentang urgensi pencatatan nikah masuk dalam rukun nikah adalah bahwa pada prinsipnya walimah, pengumuman dan saksi dalam pernikahan merupakan bentuk pengakuan dan penjaminan hak pada konteks dulu dengan kultur masyarakat lisan. Dengan alasan perubahan dan perkembangan zaman maka walimah, pengumuman dan saksi sebagai bentuk pengakuan dan penjaminan hak tidak cukup relevan lagi pada konteks sekarang dengan kultur masyarakat tulis, oleh sebab itu diperlukan suatu pencatatan nikah. 


\section{DAFTAR PUSTAKA}

Abdillah, Siti Ummu, Analisis Hukum terhadap Faktor-faktor yang Melatarbelakangi Terjadinya Nikah Siri dan Dampaknya terhadap Permpuan (Istri) dan Anak-anak, Jurnal Dinamika Hukum, Vol. 11, Februari, 2011.

al.Ghazali,.Abdul.Moqsith,.Membangun.Ușul.Fikih.Alternatif..Http://www.islamlib.com.

al-Jauziyyah, Muḥammad ibn Abī Bakr ibn Ayyub ibn Sa'ad ibn Hariz az-Zar'i ibn Qayyim,I'lām al-Muwaqqi'în 'an Rabb al-'Alamīn, Jilid II, Juz III, Kairo: Dār al-Hadis, 2002.

Ali, Mohammad Daud, Hukum Islam: Pengantar Ilmu Hukum dan Tata Hukum Islam di Indonesia, Jakarta: PT RajaGrafindo Persada, 2002.

Arsal, Thriwaty, Nikah Siri dalam Tinjauan Demografi, Solidaty: Jurnal Sosiologi Pedesaan, Vol. 6, No. 2, 2012.

Asshiddiqie, Jimly, Pengantar Ilmu Hukum Tata Negara, Jakarta: Rajawali Pers, cet. ke-3, 2011.

Biografi.Musdah.Mulia.(dalam.Buku.Muslimah.Sejati).Http://www.mujahidahmuslimah.com/m usdah-mulia/component/content/article/63-tentang-musdah-mulia/227-biografi-musdahmulia-dalam-buku-muslimah-sejati-html.

Budiono, Muhammad, Dampak Sosial Nikah Siri, Al-Hukama, Vol. 3, No. 1, Juni, 2013.

Erwin, Muhammad dan Firman Freaddy Busroh, Pengantar Ilmu Hukum, Bandung: Refika Aditama, cet. ke-1, 2012.

Fatwa Majelis Ulama Indonesia Nomor 6 Tahun 2005 Tentang Kriteria Maslahat.

Fatwa Majelis Ulama Indonesia Nomor 8 Tahun 2008 Tentang Nikah di bawah Tangan.

Gunawan, Edi, Relasi Agama dan Negara (Perspektif Pemikiran Islam, Jurnal Al-Hikmah, Vol. XV, No. 2, 2014.

Hamlan, Politik Pendidikan Islam dalam Konfigurasi Sistem Pendidikan di Indonesia, Hunafa: Jurnal Studia Islamika, Vol. 10, No. 1, Juni, 2013.

Helim, Abdul, Membangun Fikih Progressif Mazhab Indonesia (Eksistensi Pencatatan Akad Nikah dalam Hukum Perkawinan Islam Indonesia), In: AICIS 12, 2012.

Instruksi Presiden RI Nomor 1 Tahun 1991 Tentang Kompilasi Hukum Islam. 
Irwansyahbana, Tengku, Sistem Hukum Perkawinan pada Negara Hukum Berdasarkan Pancasila, Jurnal Ilmu Hukum, Vol. 3, No. 1, 2012.

Juni, M. Efran Helmi, Filsafat Hukum, Bandung: Pustaka Setia, cet. ke-1, 2012.

Kharlie, Ahmad Tholabi, Hukum Keluarga Indonesia, Jakarta: Sinar Grafika, cet. ke-1, 2013.

KPAI:Nikah.Siri.bisa.Berdampak.Buruk.ke.Anak,Http://news.merahputih.com/nasional/2015/03/ 24/kpai-nikah-siri-bisa-berdampak-buruk-ke-anak/9465/.

Masruhan, Pembaharuan Hukum Pencatatan Perkawinan di Indonesia Perspektif Maqasid Syariah, Al-Tahrir, Vol. 13, No. 2, November, 2013.

Mulia, Siti Musdah, Counter Legal Draft Kompilasi Hukum Islam, Jurnal Perempuan 45, No. 45, Januari, 2006.

Mulia, Siti Musdah, Muslimah Reformis: Perempuan Pembaru Keagamaan, Bandung: Mizan, cet. ke-1, 2005.

,al-Fiqhu al-Islāmiy wa Adillatuhu, diterjemahkan oleh Abdul Hayyie alKattani dengan judul "Fiqh Islami wa Adillatuhu Jilid 9", Jakarta: Gema Insani, cet. ke-1, 2011.

MK, Anshary, Hukum Perkawinan di Indonesia: Masalah-Masalah Krusial, Yogyakarta: Pustaka Pelajar, cet. ke-1, 2010. , Islam Menggugat Poligami, Jakarta: PT Gramedia Pustaka Utama, cet. ke2, 2007. , Membangun Surga di Bumi: Kiat-kiat Membina Keluarga Ideal dalam Islam, Jakarta: PT Elex Media Komputindo, 2011.

Nasution, Khoiruddin, Hukum Perkawinan 1: Dilengkapi Perbandingan UU Negara Muslim Kontemporer, Yogyakarta: ACAdeMIA+TAZZAFA, 2005.

, Hukum Perdata (Keluarga) Islam Indonesia dan Perbandingan Hukum Perkawinan di Dunia Muslim,Yogyakarta: ACAdeMIA + TAZZAFA, cet. ke-1, 2009.

Peraturan Menteri Agama Republik Indonesia Nomor 11 Tahun 2007 tentang Pencatatan Nikah.

Peraturan Pemerintah RI Nomor 9 Tahun 1975 Tentang Pelaksanaan UU No. 1 Tahun 1974 Tentang Perkawinan. 
Prasetyo,.Untung,.Derajat.Hadis.Rahasiakan.Khitbah.(Pertunangan).dan.Umumkan.Pernikahan ,.Http://www.falahamnan.blogspot.co.id/2016/04/derajat-hadits-rahasiakankhitbah.html?m=1.

Profil Khoiruddin Nasution, $\quad$ Http://syariah.uin-suka.ac.id/profil-dosen/17/Prof-Dr-HKhoiruddin-Nasution-MA.html.

Putusan Mahkamah Konstitusi Nomor 46/PUU-VIII/2010.

Rumokoy, Donald Albert dan Frans Maramis, Pengantar Ilmu Hukum, Jakarta: PT RajaGrafindo Persada, cet. ke-2, 2014.

Rusyd, Ibnu, Bidayah al-Mujtahid wa Nihayah al-Muqtașid, diterjemahkan oleh Abdul Rosyad Shiddiq dengan judul "Bidayatul Mujtahid wa Nihayatul Muqatașid", Jakarta: Akbar Media Eka Sarana, 2013.

Soemadiningrat, R. Otje Salman, Rekonseptualisasi Hukum Adat Kontemporer: Telaah Kritis terhadap Hukum Adat sebagai Hukum yang Hidup dalam Masyarakat, Bandung: Alumni, cet. ke-1, 2002.

Suma, Muhammad Amin, Hukum Keluarga Islam di Dunia Islam, Jakarta: PT RajaGrafindo Persada, 2005.

Syarifuddin, Amir, Ushul Fiqh 1, Jakarta: Kencana Prenada Media Group, 2009. , Ushul Fiqh 2, Jakarta: Kencana Prenada Media Group, 2009. , Hukum Perkawinan Islam di Indonesia antara Fiqh Munakahat dan Undang-Undang Perkawinan, Jakarta: Kencana, 2006.

, Membaca Kembali 'Illah Doktrin Iddah dalam Perspektif Ușūl al-Fiqh, Jurnal Karsa, Vol. 20, No. 2, Desember, 2012.

Sufa,Afifah Zakiyah, Tinjauan Hukum Islam terhadap Fungsi Akta Nikah (Studi terhadap Pemahaman Masyarakat Desa Maguwoharjo Kecamatan Depok Kabupaten), Yogyakrta: UIN Sunan Kalijaga, 2015, t.d.

Syafrin, Nirwan, Kritik Terhadap Paham Liberalisasi Syariat Islam, Jurnal Tsaqafah, Vol. 5, No. 1, 2008.

Undang-Undang Republik Indonesia Nomor 22 Tahun 1946 Tentang Pencatatan Nikah, Talak dan Rujuk.

Undang-Undang Republik Indonesia Nomor 32 Tahun 1954 Tentang Pelaksanaan UU No. 22 tahun 1946. 
Vol. 8, No. 1, Juni 2018

Undang-Undang Republik Indonesia Nomor 1 Tahun 1974 Tentang Perkawinan.

Undang-Undang Nomor 23 Tahun 2006 Tentang Administrasi Kependudukan

Wahyudani, Zulham dan Raihanah Hj Azahari, Perubahan Sosial dan Kaitannya dengan Pembagian Harta Warisan dalam Perspektif Hukum Islam, Jurnal Ilmiah Islam Futura, Vol. 14, No. 2, Februari, 2015.

Wawancara dengan Khoiruddin tanggal 09 Oktober 2016.

Wawancara dengan Musdah tanggal 19 Desember 2016.

Yusron, Ahmad, Prosedur Pencatatan Perkawinan Menurut Undang-Undang No. 1 tahun 1974 jo. Peraturan Menteri Agama No. 11 tahun 2007 (Studi Kasus Kantor Urusan Agama Kecamatan Plered Kabupaten Cirebon), Cirebon: Fakultas Syariah IAIN Syekh Nurjati, 2011, t.d. 
